\title{
Hazard assessment at Mount Etna using a hybrid lava flow inundation model and satellite-based land classification
}

\author{
Andrew J. L. Harris • Massimiliano Favalli • Robert Wright • \\ Harold Garbeil
}

\begin{abstract}
Using a lava flow emplacement model and a satellite-based land cover classification, we produce a map to allow assessment of the type and quantity of natural, agricultural and urban land cover at risk from lava flow invasion. The first step is to produce lava effusion rate contours, i.e., lines linking distances down a volcano's flank that a lava flow will likely extend if fed at a given effusion rate from a predetermined vent zone. This involves first identifying a vent mask and then running a downhill flow path model from the edge of every pixel around the vent mask perimeter to the edge of the DEM. To do this, we run a stochastic model whereby the flow path is projected 1,000 times from every pixel around the vent mask perimeter with random noise being added to the DEM with each run so that a slightly different flow path is generated with each run. The FLOWGO lava flow model is then run down each path, at a series of effusion rates, to determine likely run-out distance for channel-fed flow extending down each path. These results are used to plot effusion rate contours. Finally, effusion rate contours are projected onto a land classification map (produced from an ASTER image of Etna) to assess the type and amount of each land cover class falling within each contour. The resulting maps are designed to provide a quick look-up capability to assess the type of land at risk from lava extending from any location at a range of likely effusion rates. For our first $(2,000 \mathrm{~m})$ vent zone case used for Etna, we find a total of area of $\sim 680 \mathrm{~km}^{2}$ is at risk from flows fed at $40 \mathrm{~m}^{3} \mathrm{~s}^{-1}$, of which $\sim 6 \mathrm{~km}^{2}$ is urban, $\sim 150 \mathrm{~km}^{2}$ is agriculture and $\sim 270 \mathrm{~km}^{2}$ is grass/woodland. The model can also be run for specific cases, where we find that Etna's 1669 vent location, if active today, would likely inundate almost $11 \mathrm{~km}^{2}$ of urban land, as well as $15.6 \mathrm{~km}^{2}$ of agricultural land, including $9.5 \mathrm{~km}^{2}$ of olive groves and $5.2 \mathrm{~km}^{2}$ of vineyards and fruit/nut orchards.
\end{abstract}

\footnotetext{
A. J. L. Harris $(\bowtie)$

Laboratoire Magmas et Volcans, Clermont Université, Université Blaise Pascal, 5 Rue Kessler, BP 10448, 63000 Clermont-Ferrand, France

e-mail: A.Harris@opgc.univ-bpclermont.fr

M. Favalli

Istituto Nazionale di Geofisica e Vulcanologia-Pisa, Via Della Faggiola, 32, 56100 Pisa, Italy

R. Wright $\cdot$ H. Garbeil

HIGP/SOEST, University of Hawai'i, 1680 East-West Road, Honolulu, HI, USA
} 
Keywords Lava flow $\cdot$ Risk $\cdot$ FLOWGO - ASTER image $\cdot$ Land classification · Mt. Etna

\section{Introduction}

Lava flow hazard results from lava's ability to burn, collapse and bury structures and vegetation. Following Blong (1984), buildings will be impacted by wall collapse (due to pressure exerted by flow), burial, ignition (to cause fire), flooding (i.e., entry of lava into rooms), uplift, transport, foundation failure and projectile impact (from clasts tumbling from lava flow fronts or margins). As a result, any man-made structure in a lava flow path will suffer damage, if not be completely destroyed, along with any household items and/or machinery not removed prior to inundation. At the same time, while communications, infrastructure and utilities will be damaged and/or buried, zones of agriculture and natural vegetation will suffer ignition and burial, all of which will impact industry, economic activity, travel and habitat, to cause displacement of human and natural communities, as well as necessitating reconstruction and/or relocation. A classic example is the inundation by lava of the town of Mascali (population 2,000) during the 1928 eruption of Mt. Etna (Sicily, Italy). Lavas from the same eruption also buried $1.6 \mathrm{~km}^{2}$ of agricultural land and cut the main railway line between Catania and Messina. The town was subsequently rebuilt and successfully re-established on a new site at a cost of 25 million lira (US\$ 1.3 million) (Duncan et al. 1996; Chester et al. 1999).

Lava flow emplacement models provide a means of assessing hazard posed by future lava flow activity in terms of their inundation potential for urban, agricultural and natural vegetation zones residing within a volcanic region. One of the first applications of a lava flow emplacement model to map and assess lava flow hazard was by Wadge et al. (1994), who used the FLOWFRONT lava flow model of Young and Wadge (1990) to map the probability of lava flow inundation at Mt. Etna. Since then, lava flow models have been used in three hazard assessment roles. First, to assess likely lava flow run-out and extent, so as to assess their potential impact on communities located on a volcano's flanks, as done for Mauna Loa (Hawai'i) by Rowland et al. (2005) and for Etna's SE flank by Crisci et al. (2008), including the metropolitan area of Catania (Crisci et al. 2003). Second, to model likely lava flow paths, as well as lengths, to aid in assessments of vulnerable zones and produce probabilistic hazard maps for lava flow inundation (e.g., Kauahikaua et al. 1995; Gomez-Fernandez 2000; Felpeto et al. 2001; Bonne et al. 2008; Favalli et al. 2009a, b). Third, to assess the potential of hazard mitigation measures, where barriers can be constructed in DEMs to examine their likely effect on diverting a flow (e.g., Chirico et al. 2009; Fujita et al. 2009) or optimal points for barrier construction (e.g., Crisci et al. 1999).

Here, we use the FLOWGO lava flow emplacement model of Harris and Rowland (2001) to assess the potential run-out distance of a channel-fed lava flow. In doing this, we aim to appraise the potential risk of lava flow inundation for points around a volcano. FLOWGO assesses the distance a control volume of lava can move down a channel before cooling and crystallizing to a point at which further forward motion is impossible. Tests at Mauna Loa, Kilauea, Mt. Etna and the Galapagos have shown that FLOWGO, when run with field observed effusion rate and appropriate thermo-rheological input parameters, provides good fits with field-measured channel-fed flow length (Harris and Rowland 2001; Rowland et al. 2005; Harris et al. 2007a). By running FLOWGO iteratively over a digital elevation model (DEM) for Mauna Loa (Hawaii), Rowland et al. (2005) were able to produce effusion rate contours. Each contour located the position on the volcano flank that 
channel-fed lava, erupted from any point around the edge of a pre-designated vent region, could extend at a given volume flux (effusion rate). Recently, FLOWGO has been updated, whereby the stochastic lava flow emplacement approach of Favalli et al. (2005) has been used to generate a family of potential flow paths extending from a designated vent, or vent region, to the edge of the DEM. This approach has been shown to produce a good approximation of the area impacted by real lava flows (e.g., Favalli et al. 2006) and is the basis of the DOWNFLOW model of Favalli et al. (2005). Wright et al. (2008) showed that combination of the two models, with FLOWGO running to obtain the distance down each flow path a lava will likely extend, provides a good fit between modelled and actual lava flow inundation zones. For this, Wright et al. (2008) used Etna's 1991-1993 eruption as a test case and satellite-derived, time-varying, lava discharge rates as an input. We use here the updated version of FLOWGO to produce effusion rate contours for Mt. Etna. Using Mt. Etna as an example, we show how model-generated effusion rate contours can be combined with satellite-derived land classification maps to assess, for a range of effusion rates and vent locations, the hazard posed by lava flow activity in terms of the type and area of land at risk from lava flow inundation.

\section{Study site: Mt. Etna and lava flow hazard}

Mt. Etna's lava flows cover an area of $1,260 \mathrm{~km}^{2}$ (Fig. 1). Effusive eruptions within this area have been frequent in historical times, with lava flows typically being fed from vent

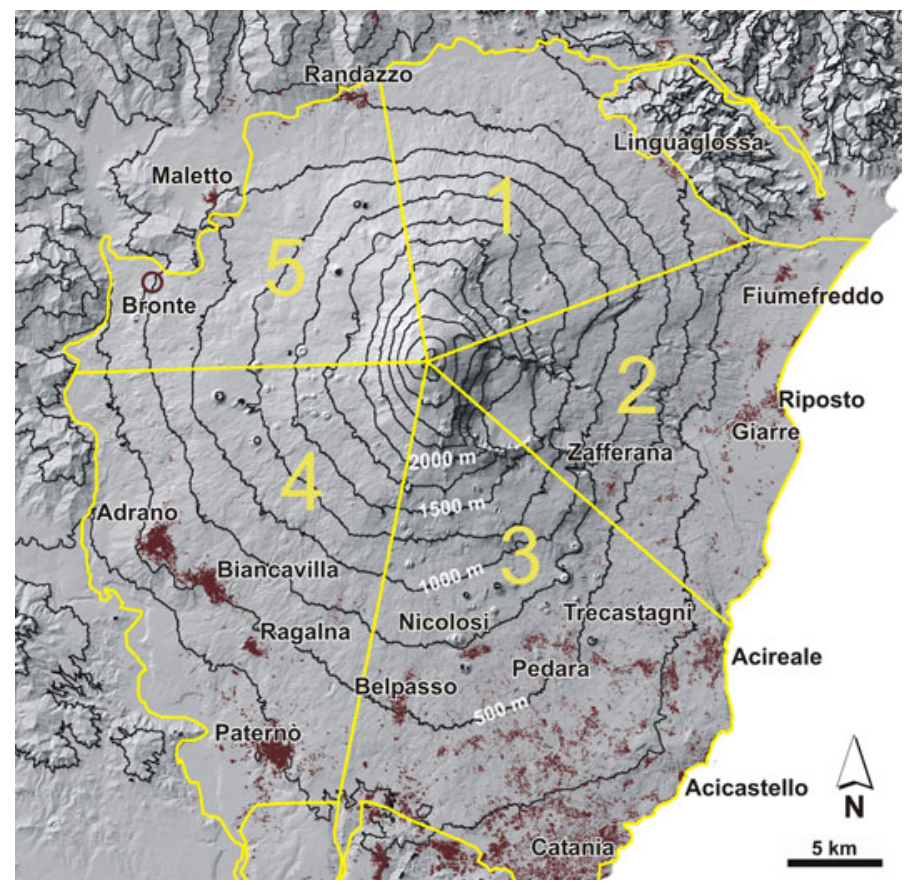

Fig. 1 Etna-shaded relief map with contours (spacing: $250 \mathrm{~m}$ ), limit of Etna volcanics (yellow line) and sectors defined in this study (numbered zones separated by radial yellow lines). Urban areas located using our ASTER land classification are projected onto the map in brown, with the selected towns and cities in each sector labelled 
zones concentrated around Etna's summit, as well as in zones extending NE, S and W from the summit (Behncke et al. 2005). Guest and Murray (1979) estimated that $200 \mathrm{~km}^{2}$ of lava was erupted over the 400-year period between 1669 and 1979 to give an average resurfacing rate of $0.5 \mathrm{~km}^{2}$ per year. At the same time, Etna's flanks are extensively cultivated with primary agricultural land uses being vineyards, orchards and olive plantations. In addition, a number of major towns and cities are located on Etna's flanks where, as of 2008, the population residing on Etna numbered almost one million (ISTAT 2008) to give a population density averaged across the entire edifice of 741 inhabitants per square kilometre. The frequency of effusive activity, high resurfacing rates, presence of extensive agricultural activities and large human population mean that lava flows often impact the human, and natural, populations.

These factors have led to several studies aimed at assessing and mapping the hazard posed by lava flow inundation at Etna (e.g., Guest and Murray 1979; Villari 1983; Forgione et al. 1989; Pareschi et al. 2000; Bisson et al. 2009), proposals to use lava flow emplacement models to map lava inundation hazard (e.g., Villari 1983; Damiani et al. 2006), as well as actual model application to assess likely inundation zones and to produce probabilistic hazard and susceptibility maps (e.g., Wadge et al. 1994; Crisci et al. 1999, 2003, 2008; Favalli et al. 2009a; Crisci et al. 2010). In addition, the wealth of data for effusive eruptions at Etna has made this location an excellent study site to test the performance of code designed to simulate lava flow emplacement. These have included the development and application of cellular automata models (e.g., Crisci et al. 1986; Barca et al. 1993; Del Negro et al. 2005), including SCIARA (Crisci et al. 2004) and MAGFLOW (Alexis et al. 2009; Del Negro et al. 2008; Vicari et al. 2007, 2009). The LavaSIM code of Hidaka et al. (2005) has also been applied to simulate Etna's 2001 lava flows by Proietti et al. (2009). In addition, more simple downhill spreading and flow path models have been built and applied using topographic data for Mt. Etna (e.g., Young and Wadge 1990; Barberi et al. 1993; Pareschi et al. 2000; Bisson et al. 2009). Indeed the two lava flow emplacement models combined here (DOWNFLOW and FLOWGO) were initially tested using historical eruption data from Mt. Etna (Harris and Rowland 2001; Favalli et al. 2005; Wright et al. 2008). This not only reflects the value of Etna as a perfect target for testing lava flow inundation simulations, but also means that any results will be of use for future hazard planning at Etna.

\subsection{Land cover and population by elevation and sector}

Three broad categories of land cover at risk from lava inundation can be defined on Etna: unvegetated (including urban zones and lava desert), natural vegetation and agriculture. The exact mix of land use that comprises each will vary depending on elevation and aspect.

Both natural vegetation and crops have altitudinal limits, so that Poli Marchese (1991) define three vegetation zones by altitude at Etna. The basal Mediterranean zone extends from sea level to $1,450 \mathrm{~m}$ and includes agricultural activities, chestnut woodland and deciduous oak. Above this, the Mediterranean mountain zone extends between 1,450 and 2,100 m, with the high Mediterranean zone covering land above 2,100 m. Above 2,950 m, barren volcanic desert extends to the volcano summit at $\sim 3,350 \mathrm{~m}$. Within the lowest two zones, natural vegetation is dominated by woodland, whose characteristics are given in Table 1. The dominant woodland types tend to be found across all sectors of the volcano, so that their distribution tends to be controlled mainly by altitude (Table 1). Main cultivated species on Etna are fruits (including citrus), vines, olives and pistachio. These species have relatively low altitudinal limits. While citrus fruits have an altitudinal limit of 
Table 1 Main woodland types on Mt. Etna defined by Puzzolo and Folving (2001), with per cent cover accounted for by each type (out of total wooded area), altitudinal limits and sectors in which each type is found

\begin{tabular}{|c|c|c|c|c|}
\hline Woodland type & Per cent cover & Main species & $\begin{array}{l}\text { Species } \\
\text { altitudinal } \\
\text { limits }\end{array}$ & Sectors \\
\hline Evergreen Mediterranean & 40 & Evergreen Oak (Quercus ilex) & $1,800 \mathrm{~m}$ & All \\
\hline Chestnut & 18 & Chestnut (Castanea sativa) & $1,400 \mathrm{~m}$ & $\begin{array}{l}\text { NE, E, SE, } \\
\quad \text { S, SW }\end{array}$ \\
\hline Deciduous Oak & 13 & $\begin{array}{c}\text { Deciduous Oak (Quercus } \\
\text { pubescens and cerris) }\end{array}$ & $\begin{array}{l}1,200 \mathrm{~m} \text { and } \\
800 \mathrm{~m}\end{array}$ & All \\
\hline Pine & 13 & Pine (Pinus laricio) & $1,800 \mathrm{~m}$ & NE, SW \\
\hline Beech & 6 & Beech (Fagus sylvatica) & $2,000 \mathrm{~m}$ & $\mathrm{~N}, \mathrm{NW}$ \\
\hline Mixed Oak and Pine & 4 & $\begin{array}{l}\text { (Quercus ilex and Pinus } \\
\text { laricio) }\end{array}$ & $1,800 \mathrm{~m}$ & $\mathrm{NE}, \mathrm{E}$ \\
\hline $\begin{array}{l}\text { Mixed Pine and } \\
\text { Broadleaf }\end{array}$ & 3 & & $1,800 \mathrm{~m}$ & NW \\
\hline Birch & 3 & Birch (Betula aetnensis) & $2,000 \mathrm{~m}$ & $\mathrm{NE}, \mathrm{E}$ \\
\hline
\end{tabular}

Data from Chester et al. (1985), Puzzolo and Folving (2001) and Testi (2003)

$550 \mathrm{~m}$ on Etna's south-west flank (Chester et al. 1985), the limit for vines and olives is $900 \mathrm{~m}$ (Testi 2003). Thus, cultivation tends to occur below the 1,000 $\mathrm{m}$ contour and is controlled by aspect below this level. While citrus fruits tend to be grown mainly on the warmer, wetter, south and east flanks, vines are found on all flanks except for the arid west flank, and olives are mainly grown on the dry west and south-west flanks (Chester et al. 1985), with olives found increasingly mixed with Indian fig as conditions become drier. Finally, pistachio is primarily cultivated on the west flank.

Population is dense, but unevenly distributed around the volcano (Fig. 1), with the main population centres being located in the southern and eastern sectors of the volcano, as listed in Table 2. The south-eastern sector includes the largest municipality on Etna, Catania. This municipality, as of 2008, had a population of 298,957 (Table 2) and covered an area of $180.88 \mathrm{~km}^{2}$ (ISTAT 2008) to give a population density of 1,653 inhabitants per square kilometre.

On the basis of this agricultural and population distribution, we split the volcano into five sectors, each of which are characterised by different population densities and land cover types at risk from lava inundation:

- Sector $1(\mathrm{~N})$ : Low population density (63 inhabitants $/ \mathrm{km}^{2}$ ), vine dominated.

- Sector 2 (E): Moderate population density (408 inhabitants $\left./ \mathrm{km}^{2}\right)$, lemon dominated.

- Sector 3 (SE): High population density $\left(1,940\right.$ inhabitants $\left./ \mathrm{km}^{2}\right)$, urban with olive, plus orchards at higher elevations.

- Sector 4 (SW): Moderate population density (373 inhabitants $/ \mathrm{km}^{2}$ ), with olive, Indian fig and pistachio (orchards at higher elevations).

- Sector 5 (NW): Low population density (207 inhabitants $\left./ \mathrm{km}^{2}\right)$, arid.

These five sectors are delimited on Fig. 1, with the population of the municipalities contained within each sector being given in Table 2. Sectors 2, 3 and 4 are the primary urban areas containing $95 \%$ of the population defined in Table 2 . Sector 3 is particularly urban containing $72 \%$ of Etna's population. 
Table 2 Population of each of Etna's 42 municipalities (population data from ISTAT 2008), broken out by sector (as located in Fig. 1)

\begin{tabular}{|c|c|c|c|c|c|}
\hline \multirow[t]{2}{*}{ Sector } & \multirow[t]{2}{*}{ Municipality } & \multirow[t]{2}{*}{ Inhabitants } & \multicolumn{3}{|l|}{ Sector } \\
\hline & & & Subtotal & Area $\left(\mathrm{km}^{2}\right)$ & Inhabitants $/ \mathrm{km}^{2}$ \\
\hline \multirow[t]{3}{*}{1} & Linguaglossa & 5,459 & & & \\
\hline & Piedimonte Etneo & 3,946 & & & \\
\hline & Castiglione di Sicilia & 3,429 & 12,834 & 202 & 63 \\
\hline \multirow[t]{9}{*}{2} & Giarre & 27,108 & & & \\
\hline & Riposto & 14,962 & & & \\
\hline & Mascali & 13,039 & & & \\
\hline & Fiumefreddo di Sicilia & 9,740 & & & \\
\hline & Zafferana Etnea & 9,051 & & & \\
\hline & Santa Venerina & 8,274 & & & \\
\hline & Calatabiano & 5,392 & & & \\
\hline & Sant'Alfio & 1,686 & & & \\
\hline & Milo & 1,057 & 90,309 & 221 & 408 \\
\hline \multirow[t]{22}{*}{3} & Catania & 298,957 & & & \\
\hline & Acireale & 52,862 & & & \\
\hline & Misterbianco & 47,912 & & & \\
\hline & Aci Catena & 28,434 & & & \\
\hline & Gravina di Catania & 27,808 & & & \\
\hline & Mascalucia & 27,482 & & & \\
\hline & Belpasso & 23,606 & & & \\
\hline & San Giovanni la Punta & 22,136 & & & \\
\hline & Tremestieri Etneo & 21,520 & & & \\
\hline & Aci Castello & 18,107 & & & \\
\hline & Aci Sant'Antonio & 17,188 & & & \\
\hline & Pedara & 12,283 & & & \\
\hline & San Gregorio di Catania & 11,307 & & & \\
\hline & Motta Sant'Anastasia & 11,203 & & & \\
\hline & Trecastagni & 9,769 & & & \\
\hline & Sant'Agata li Battiati & 9,690 & & & \\
\hline & Viagrande & 7,707 & & & \\
\hline & Valverde & 7,588 & & & \\
\hline & Nicolosi & 6,959 & & & \\
\hline & San Pietro Clarenza & 6,670 & & & \\
\hline & Camporotondo Etneo & 3,805 & & & \\
\hline & Aci Bonaccorsi & 2,927 & 675,920 & 348 & 1,940 \\
\hline \multirow[t]{5}{*}{4} & Paterno’ & 49,331 & & & \\
\hline & Adrano & 36,413 & & & \\
\hline & Biancavilla & 23,567 & & & \\
\hline & Santa Maria di Licodia & 6,851 & & & \\
\hline & Ragalna & 3,468 & 119,630 & 321 & 373 \\
\hline
\end{tabular}


Table 2 continued

\begin{tabular}{llrrrr}
\hline Sector & Municipality & Inhabitants & \multicolumn{2}{l}{ Sector } & \\
\cline { 5 - 5 } & & & Subtotal & Area $\left(\mathrm{km}^{2}\right)$ & Inhabitants $/ \mathrm{km}^{2}$ \\
\hline 5 & Bronte & 19,332 & & & \\
& Randazzo & 11,228 & & & 207 \\
\multirow{2}{*}{ All } & Maletto & 4,092 & 34,652 & 167 & 741 \\
\hline
\end{tabular}

Municipalities within each sector are sorted by population. Population density is given for each sector

In terms of volcanic hazard, sector 1 includes the north sector of Behncke et al. (2005), a sector that has witnessed one eruption every 13.5 years between 1600 and 2005 . Sectors 2 and 3 coincide with the Behncke et al. (2005) south sector, a sector that has experienced one eruption every 15 years over the same period. Following the same study, sectors 4 and 5 have experienced one eruption every $\sim 50$ years. Thus, in terms of historical eruption frequency, sector 1 is the most hazardous, closely followed by sectors 2 and 3 , and finally sectors 4 and 5 .

We next assess and quantify the specific land use types at risk from lava inundation by first running a lava flow inundation model to produce lava effusion rate contours and then overlaying these on a satellite-data-derived land classification map. This provides a twopart method by which the type and quantity of land at risk from lava flow inundation can be mapped and reported.

\section{Method part I: iterative model runs for effusion rate contour generation}

Application of the FLOWGO model to generate the lava flow inundation map involves three steps: (1) identification of vent zones, (2) projection of likely paths for lava flows extending from the vent region and (3) estimation of the distance down each path a lava flow may extend at a given effusion rate.

\subsection{Step 1: identification of vent zones}

As a first step, we needed to define the starting points for our lava flow emplacement model runs. This involved definition of two vent zones. The first vent zone, as defined by Favalli et al. (2009a), considers the 2,000-m contour as the limit for vent opening that typically feeds recent (1989-2009) effusive activity. All lava flows active on Etna since 1989 have been fed by vents located above this elevation. The lowest vent active on Etna's south flank during the 2001 eruption, for example, opened at 2,100 m. This first vent zone limit is given in Fig. 2a. The second vent zone was defined by Guest and Murray (1979) and considers a zone within which there is more than one vent per $\mathrm{km}^{2}$. We use the version of Guest and Murray (1979) vent zone, modified by Favalli et al. (2009a) who remapped the vent distribution using scoria cone locations from LIDAR data. This vent zone limit is given in Fig. 2b. Although it would be most simple to use a single vent zone, we feel the use of two is more appropriate. All eruptions at Etna between 1975 and 2005, a total of 35, have occurred from vent locations above the 2,000-m elevation (Behncke et al. 2005). The last eruption to occur from a vent below 2,000 m was that of 1974, which was fed by a vent 

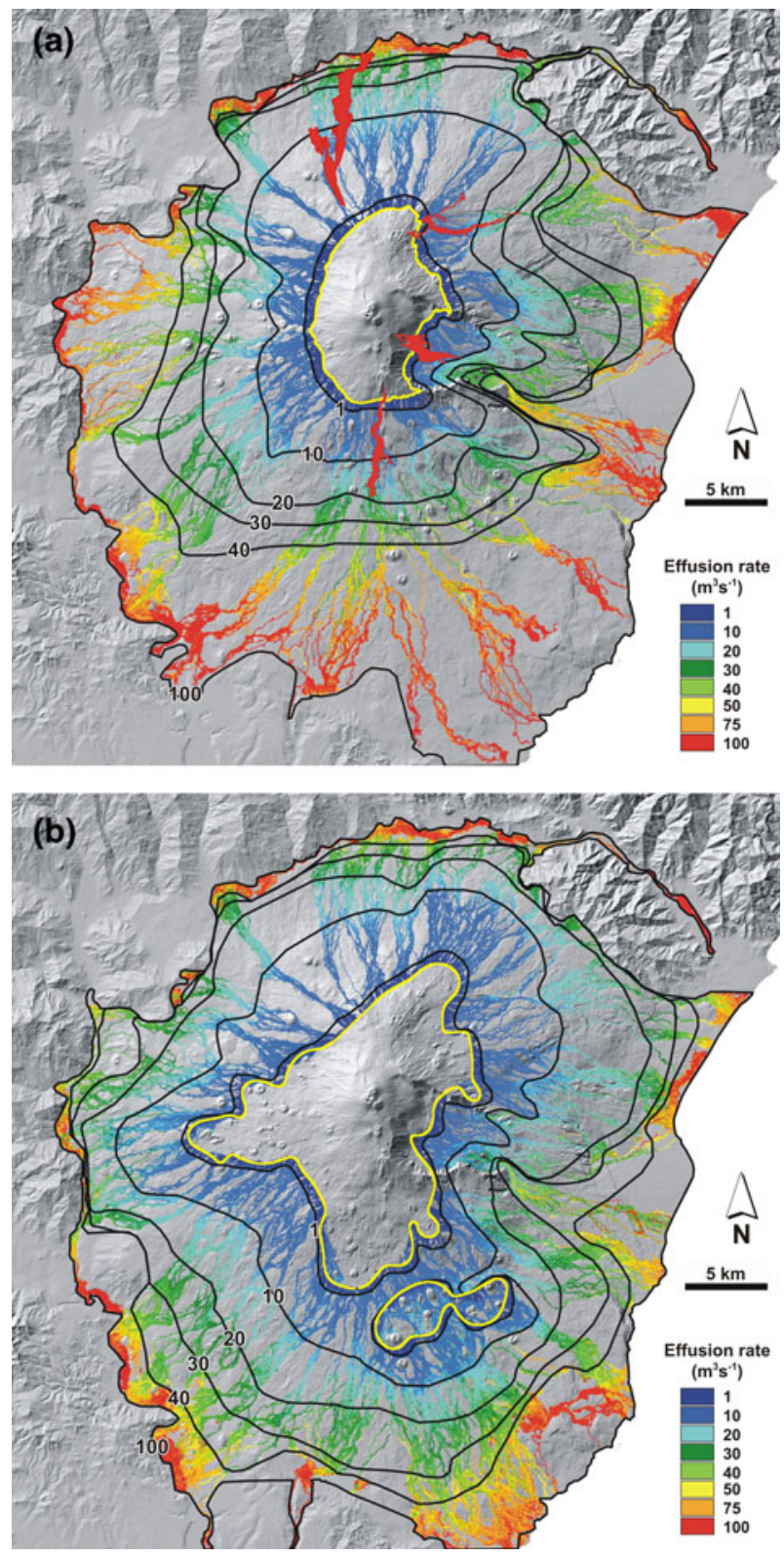

Fig. 2 FLOWGO simulation results when run from (a) the 2,000-m vent zone, and (b) the modified Guest and Murray (1979) vent zone. Vent zone perimeters are outlined in yellow, and all flow paths from the perimeter of each vent zone are given. Distance down each flow path that channel-contained lava can extend at a given effusion rate is given using a colour code (see key). The effusion rate contours (effusion rate labelled black lines) link points of maximum distance that a lava flow will likely extend if fed at a given effusion rate. The extent of Etna's 1981 (NW flank), LSF1 2001 (S flank), 2002 (NW flank), and 2004-2005 (summit) flow fields are given in red in (a) 
at 1,650 $\mathrm{m}$ (Behncke et al. 2005). Thus, the 2,000-m vent zone appears most appropriate for current activity. However, the map of Guest and Murray (1979) shows that vents can open at lower elevations, thereby placing the source lower on the flanks and closer to, or within, sensitive natural and human populations. Del Carlo and Branca (1998), for example, identify nine post 122 BC vents on Etna's SE flank between the 500 and 1,800-m elevations. Thus, we use the Guest and Murray (1979) vent zone for a worst case scenario assessment.

\subsection{Step 2: projection of likely lava flow paths}

Next, we ran the lava flow path model from every pixel around the perimeter of each vent zone. To do this, we ran a downhill drainage model (e.g., Glaze and Baloga 2001) over a 10-m resolution DEM generated for Etna using LIDAR data collected in 2005 (Favalli et al. 2009a). The flow path model was run iteratively from each pixel around the vent zone perimeter (i.e., every $10 \mathrm{~m}$ around the vent zone perimeter) following the stochastic approach of Favalli et al. (2005). That is, downhill flow paths were projected from the edge of the vent zone to the edge of the DEM or sea level (whichever limit was encountered first). Random noise (i.e., a uniformly distributed random height variation with a maximum variation of $\Delta \mathrm{h}$ ) was then added to the DEM at each pixel location and the flow path recalculated. Following Favalli et al. (2005), we used $\Delta \mathrm{h}$ of $\pm 3 \mathrm{~m}$ and completed 1,000 iterations from each starting pixel.

\subsection{Step 3: estimation of flow run-out}

Finally, the FLOWGO model was applied to assess the distance down each flow line a channel-contained control volume of lava could extend at a given effusion rate. To do this, we used the FLOWGO thermal-rheological input parameters defined for Etna by Harris et al. (2007a), coupled with the effusion rate fitting adaptation applied to FLOWGO by Rowland et al. (2005). This assumes an initial (at-vent) square channel, of width $w$ and depth $d$ (so that $w=d$ ), and iterates on channel depth to obtain the required effusion rate. Note here that starting velocity $(V)$ is obtained from channel depth and underlying slope (Harris and Rowland 2001). Thus, channel depth can be adjusted until a velocity is obtained that gives the required effusion rate $\left(E_{r}\right)$, where (for the square channel case) $E_{r}=w d V=d^{2} V$.

FLOWGO runs down each flow line were completed for a series of effusion rates $(1,10$, $20,30,40,50,75$ and $\left.100 \mathrm{~m}^{3} \mathrm{~s}^{-1}\right)$. These effusion rate steps were selected as being typical of Etna's recent effusive activity. Peak effusion rates of between 15 and $25 \mathrm{~m}^{3} \mathrm{~s}^{-1}$ were recorded during the early stages of Etna's 1991-1993 flank eruption (Calvari et al. 1994; Harris et al. 1997), with $20-30 \mathrm{~m}^{3} \mathrm{~s}^{-1}$ being witnessed during initial emplacement of lava flow unit LSF1 on Etna's south flank during the 2001 eruption (Behncke and Neri 2003; Coltelli et al. 2007). Highest effusion rates reported during the last 30 years at Etna were $\sim 130 \mathrm{~m}^{3} \mathrm{~s}^{-1}$ during the March 1980 flank eruption (Guest et al. 1987), 50-60 $\mathrm{m}^{3} \mathrm{~s}^{-1}$ during the 1983 flank eruption (Frazzetta and Romano 1984; Harris et al. 2000) and $60-120 \mathrm{~m}^{3} \mathrm{~s}^{-1}$ during fountain-fed phases of the 1999 summit eruption (Harris and Neri 2002). However, effusion rates are typically between 1 and $10 \mathrm{~m}^{3} \mathrm{~s}^{-1}$ during the later stages of flank eruptions (e.g., Frazzetta and Romano 1984; Calvari et al. 1994; Coltelli et al. 2007) and non-fountain-fed summit eruptions (e.g., Harris et al. 2000; Calvari et al. 2003; Lautze et al. 2004). 
Each flow line was then colour coded depending on the effusion rate (Fig. 2). Finally, effusion rate contours were drawn linking run-out distances for runs of equal effusion rate. This was done for both the 2,000-m vent zone (Fig. 2a) and the Guest and Murray (1979) vent zone (Fig. 2b) cases. The result, as given in Fig. 2, provides a quick look lava flow inundation hazard map for lava flows from any vent position and fed at effusion rates of between 1 and $100 \mathrm{~m}^{3} \mathrm{~s}^{-1}$.

\section{Method part II: land classification using satellite imagery}

To assess the type of land at risk from lava flow inundation, we completed a satelliteimage-based land classification (Fig. 3). Land classification is a standard procedure in remote sensing whereby the multispectral information for each pixel in an image is analysed to identify, distinguish and group different land cover types (e.g., Mather 1987; Lillesand and Kiefer 1987). As part of this process, pixels are assigned to a class (Mather 1987) or group (Lillesand and Kiefer 1987) depending on their characteristic spectral features. An unsupervised classification determines groups of pixels on the basis of non-overlapping spectral characteristics, so that each pixel group is termed a spectral

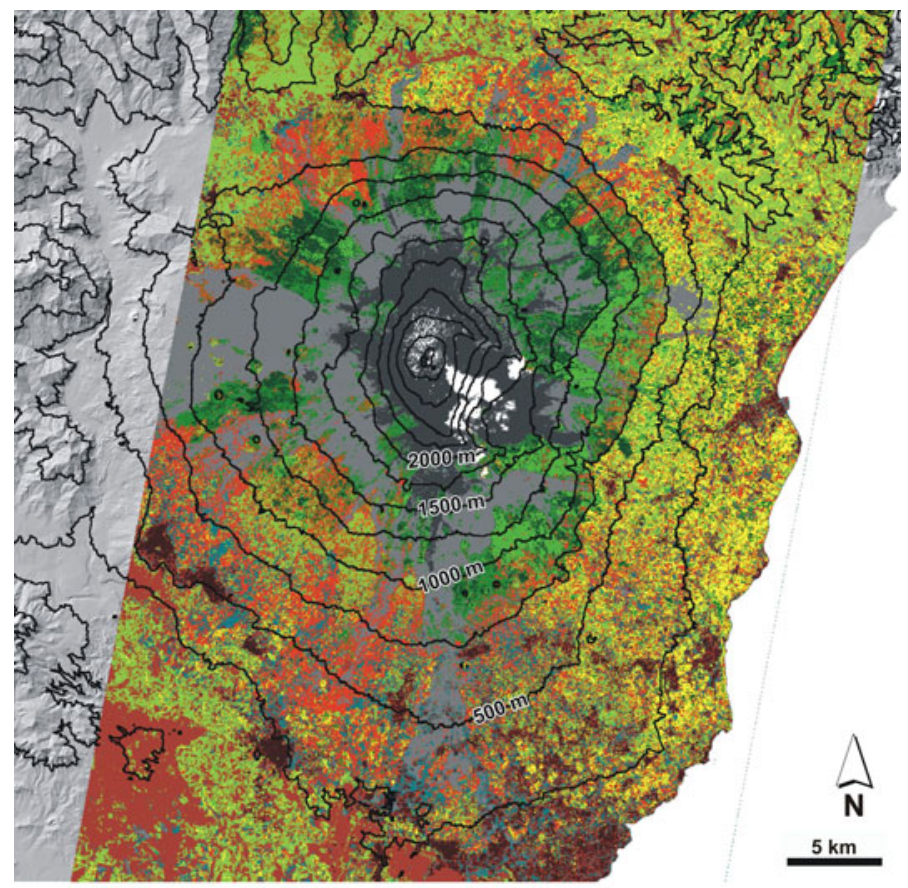

Land classification

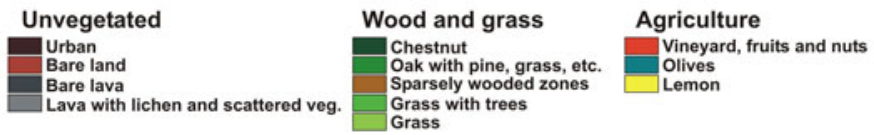

Fig. 3 Land classification map of Mt. Etna derived from a 26th June 2004 ASTER image, with elevation contours overlain $($ white $=$ cloud $/$ condensed volcanic plume) 
class (Mather 1987) or cluster (Lillesand and Kiefer 1987). Field work can then be carried out to assign each spectral class to a specific land cover type (Lillesand and Kiefer 1987). This allows each pixel group to be related to an actual land cover type, so that the pixel groups can be termed information classes (Mather 1987).

To complete our land classification, as given in Fig. 3, we used a cloud-free image obtained for Etna by the Advanced Spaceborne Thermal Emission and Reflection Radiometer (ASTER) on 26 June 2004. ASTER collects data in three 15-m spatial resolution bands spanning the visible (VIS) to near-infrared (NIR) portion of the spectrum, and six 30-m spatial resolution bands spanning the short-wave infrared (SWIR). We first carried out an unsupervised classification that identified 15 spectral classes on the basis of their spectral features as recorded by ASTER's VIS, NIR and SWIR bands. A k-means classifier was used to identify spectral clusters in the image data. This algorithm uses a set of initial class means evenly distributed in the n-dimensional data space, then iteratively clusters image pixels into the nearest class using a minimum distance to means technique. With each iteration, new class means are calculated and the pixels are reclassified with respect to these new means. In this study, the iterative process ended when the number of pixels in each class changed by less than $2.5 \%$. We converted the spectral classes to information classes through field work during June 2005. This involved a ground-based survey during which approximately 50 GPS-located field control sites were visited to check the land cover type associated with each spectral class. This allowed us to convert the spectral classes to information classes, so that each pixel grouping was assigned a land cover type. As part of this process, the number of classes was reduced to 12 by combining three of the 15 spectral classes into a single information class (vineyard, fruit and nuts) to avoid problems of misclassification.

The information classes could, in turn, be grouped into three categories: unvegetated (including urban, bare lava and lava with scattered shrub), natural vegetation (including woodland and grass) and agricultural. Within the natural vegetation category, Puzzolo and Folving (2001) distinguish eight types of woodland for Mt. Etna, as given in Table 1. Although we distinguish between chestnut and oak/pine woodland, these being the dominant woodland species on Etna (accounting for $84 \%$ of the woodland species of Table 1), we do not distinguish between the other woodland types of Table 1. Within the agricultural category, although we could identify olives and lemons, we could not distinguish between vineyards, fruit orchards and nut plantations. Thus, these latter land cover types appear as a single class: vineyard, fruits and nuts. Within this class, fruits include apple, pear and berry, such as gelso nero (Morus nigra), as well as various Prunus species, such as apricot (Prunus armeniaca), peach (Prunus persica) and mandorlo (Prunus dulcis). Each of the categories, along with the information classes that comprise each category, are given in Table 3. Note that the total area covered by the classification $\left(\sim 1,200 \mathrm{~km}^{2}\right)$ is a little less than Etna's actual area $\left(1,260 \mathrm{~km}^{2}\right)$. This difference is due to a small strip of the edifice falling beyond the western edge of our ASTER image (Fig. 3).

In July 2006, we completed a second field survey, again visiting around 50 GPS-located field control sites to check that assigned information classes matched the actual land cover type within each pixel. We found just two cases of misclassification, both of which were due to a land cover type being spectrally similar (at the wavebands considered) to a different class. The first zone of misclassification was located on pre-historic lavas on Etna's west flank SE of Bronte. This zone had been assigned to the vineyard-fruit-nuts information class, but was actually mixed woodland. The second zone was located on Etna's east flank on the 1651 flow field. This zone had also been assigned to the vineyardfruit-nuts information class, but consisted of sparse vegetation cover on lichen-covered lava. Both were reassigned to their correct information classes. Our corrected supervised 
Table 3 Land classification categories, classes, elevation ranges and areas (data given by sector and as totals)

\begin{tabular}{|c|c|c|c|c|c|c|c|c|}
\hline \multirow[t]{2}{*}{ Category } & \multirow[t]{2}{*}{ Information class } & \multirow[t]{2}{*}{$\begin{array}{l}\text { Elevation range } \\
(\mathrm{m})\end{array}$} & \multicolumn{5}{|c|}{$\begin{array}{l}\text { Area occupied by each land cover } \\
\text { type, by sector }\left(\mathrm{km}^{2}\right)\end{array}$} & \multirow[t]{2}{*}{$\begin{array}{l}\text { Total } \\
\left(\mathrm{km}^{2}\right)\end{array}$} \\
\hline & & & 1 & 2 & 3 & 4 & 5 & \\
\hline \multicolumn{3}{|l|}{ Unclassified } & 0.7 & 3.9 & 2.4 & 0.1 & 0.5 & 7.5 \\
\hline \multirow[t]{4}{*}{ Unvegetated } & Urban & $0-1,000$ & 1.0 & 5.4 & 28.8 & 13.4 & 1.0 & 49.6 \\
\hline & Bare land & - & 4.7 & 9.8 & 42.3 & 34.1 & 2.1 & 93.1 \\
\hline & Bare lava & 1,000 to $>3,000$ & 21.8 & 15.6 & 18.6 & 8.5 & 14.4 & 78.9 \\
\hline & $\begin{array}{l}\text { Lava w/lichen and scattered } \\
\text { veg. }\end{array}$ & 0 to $>3,000$ & 40.6 & 18.9 & 49.1 & 45.8 & 51.2 & 205.6 \\
\hline \multirow[t]{5}{*}{ Natural veg. } & Chestnut & $0-2,250$ & 22.6 & 22.8 & 9.8 & 7.4 & 14.4 & 77.0 \\
\hline & Oak/pine, grass, etc. & $0-2,500$ & 16.8 & 14.5 & 17.1 & 16.7 & 11.5 & 76.6 \\
\hline & Sparsely wooded & $0-2,000$ & 9.7 & 6.1 & 4.4 & 12.1 & 14.2 & 46.5 \\
\hline & Grass w/trees & $0-2,000$ & 10.2 & 20.4 & 10.7 & 2.4 & 4.3 & 48.1 \\
\hline & Grass & $0-1,500$ & 21.2 & 23.4 & 40.0 & 48.5 & 11.4 & 144.4 \\
\hline \multirow[t]{3}{*}{ Agriculture } & Vineyard, fruit and nuts & $0-1,500$ & 28.3 & 21.2 & 53.9 & 55.9 & 14.4 & 173.7 \\
\hline & Olive & $0-1,250$ & 9.4 & 10.2 & 49.0 & 32.6 & 2.8 & 104.0 \\
\hline & Lemon & $0-500$ & 15.5 & 48.0 & 22.0 & 5.6 & 0.2 & 91.4 \\
\hline Unvegetated & All classes & 0 to $>3,000$ & 68.0 & 49.7 & 138.8 & 101.9 & 68.8 & 427.1 \\
\hline Natural veg. & All classes & $0-2,500$ & 80.6 & 87.2 & 82.1 & 87.2 & 55.7 & 392.6 \\
\hline Agriculture & All classes & $0-1,500$ & 53.1 & 79.4 & 125.0 & 94.2 & 17.4 & 369.0 \\
\hline Total & $\begin{array}{l}\text { All classes (including } \\
\text { unclassified) }\end{array}$ & 0 to $>3,000$ & 202.4 & 220.1 & 348.2 & 283.3 & 142.3 & 1196.3 \\
\hline
\end{tabular}

classification is given in Fig. 3 which, in effect, represents a digital land cover map of Mt. Etna for June 2004. The proportion and area occupied by each land cover class was then plotted by sector (Fig. 4) and altitude (Fig. 5).

\subsection{Output: merging of effusion rate contours and land classification maps}

The final step was to overlay the effusion rate contours onto the land classification map, as done in Fig. 6. This allows visual assessment of the elevation, and hence land use, impacted by flows of increasing effusion rate. However, it gives no information about likely flow paths. Placing the full flow path map of Fig. 2 onto the land classification means that the flow path zones obscure the land cover information. Thus, to simplify matters and avoid obscuration of crucial information (i.e., the type of land that will fall within each effusion rate contour), we plotted the main drainage routes for lava flowing from each vent zone to the DEM edge, along with the effusion rate contours using a simple drainage model. The result is given in Fig. 7. While the drainage routes give an idea of likely flow paths, as well as shadow zones where land is topographically protected from flow inundation, the effusion rate contours give a guide to how far down each route a lava flow will likely extend at a given effusion rate. We over-plotted these simplified effusion rate contour maps with individual information classes, where the urban class is plotted on Fig. 7. This allows the location of each class to be assessed in relation to potential lava flow paths and effusion rate contours. Finally, the area of each land cover type within a given effusion rate contour was tabulated (Tables 4 and 5) and plotted (Fig. 8). 


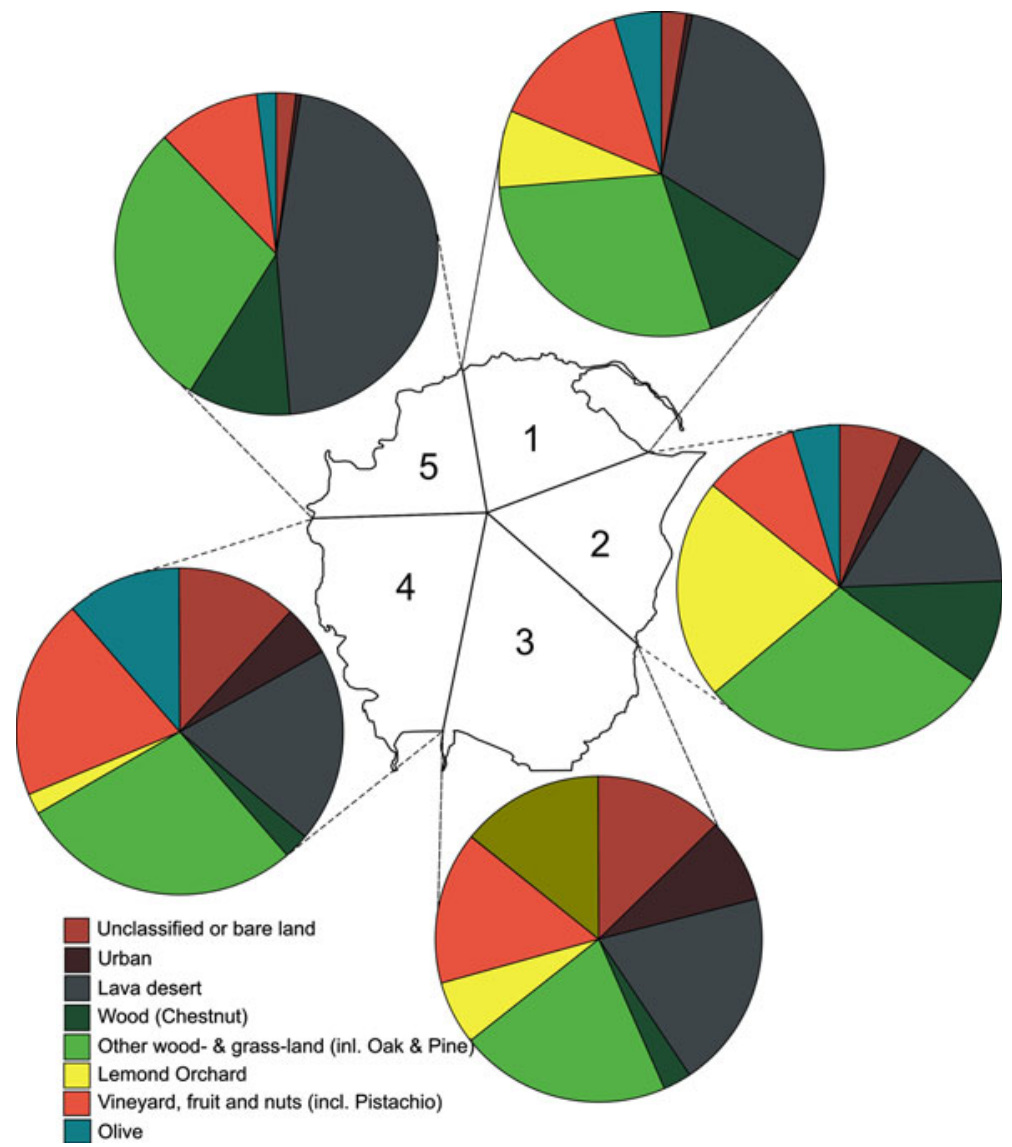

Fig. 4 Pie charts showing relative extent of each land cover type within each sector

Of course, the simple drainage model given in Fig. 7 is not very informative in terms of likely flow inundation area. For an idea of the actual spread of likely flow paths from each vent zone, the analyst can turn to the maps of Fig. 2 in which the full flow path information is given. Alternatively, the model can be run from a single starting point to gain an idea of the likely coverage for a given eruption scenario, as done in Fig. 9. Note, though, that projection of all of the possible flow paths for the Fig. 9 scenario (the result of 10,000 iterations) onto the land classification map now masks the land cover information. In short, if we project all of the flow lines over the classification map, we do not see any of the land type information. This is one reason why we adopt the effusion rate contour approach.

\section{Results 1: lava flow inundation zones}

\subsection{Effusion rate contours: validation}

We checked the FLOWGO-model-predicted effusion rate contours for four cases: the 1981 NW flank flow, the 2001 south flank flow LSF1, the 2002 NE flank flow and the 


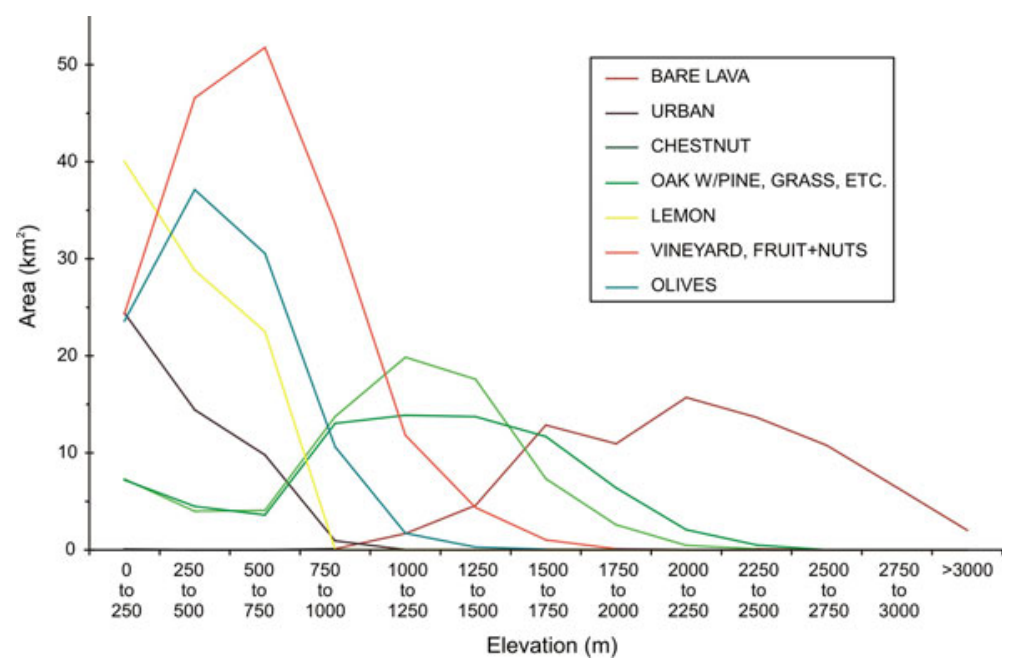

Fig. 5 Variation of land cover type with elevation, given in terms of total area of each land class (for all sectors) falling within each 250-m elevation increment

2004-2005 summit flow field. All four flows had their main vent approximately at the edge of our 2,000-m vent zone (Fig. 2a), and so are good cases against which to compare our model runs.

Of these cases, the 1981 flow was fed by the highest effusion rates (up to $128 \mathrm{~m}^{3} \mathrm{~s}^{-1}$, Guest et al. 1987). It was thus able to extend to the base of the edifice at which point it moved into the Alcantara river channel. We therefore expect it to extend through our $100 \mathrm{~m}^{3} \mathrm{~s}^{-1}$ contour that extends to the edge of the Etna volcanic zone, as it does (Fig. 2a).

Flow LSF1 was active during Etna's 2001 eruption and was fed for 42 days at timeaveraged discharge rates [see Harris et al. (2007b) for definition] that varied between 0.4 and $31 \mathrm{~m}^{3} \mathrm{~s}^{-1}$ (Coltelli et al. 2007). Time-averaged discharge rates of between 24 and $18 \mathrm{~m}^{3} \mathrm{~s}^{-1}$ were obtained on 20 and 26 July (Coltelli et al. 2007). At this time, the maximum flow length of $6.4 \mathrm{~km}$ was attained. Thus, we expect the mapped flow front to coincide with our $20 \mathrm{~m}^{3} \mathrm{~s}^{-1}$ contour, which it does (Fig. 2a).

A mean output rate [see Harris et al. (2007b) for definition] of between 10 and $15 \mathrm{~m}^{3} \mathrm{~s}^{-1}$ was obtained by Andronico et al. (2005) for Etna's 2002 NE flank flow. These values are time-averaged over the entire eruption so that actual instantaneous effusion rates were likely higher, where satellite-based measurements [following the method of Harris et al. (1997)] yielded effusion rates in the range $10-26 \mathrm{~m}^{3} \mathrm{~s}^{-1}, 13-33 \mathrm{~m}^{3} \mathrm{~s}^{-1}$ and $12-31 \mathrm{~m}^{3} \mathrm{~s}^{-1}$ on the 27th, 28th and 29th of October, respectively (Harris, unpublished data). This is consistent with flow front for this lava attaining our $20 \mathrm{~m}^{3} \mathrm{~s}^{-1}$ contour (Fig. 2a).

Etna's 2004-2005 was characterised by eruption of degassed lava from two vents at 2,640 and 2,345 m on Etna's east flank to build a compound lava flow field of many overlapping units. After 3 months of eruption, lava volumes were estimated to be between 18.5 and $32 \times 10^{6} \mathrm{~m}^{3}$ to give a mean output rate averaged over the 3-month period of 2.3 and $4.1 \mathrm{~m}^{3} \mathrm{~s}^{-1}$ (Burton et al. 2005). Again, actual effusion rates would have been higher at times, with a maximum effusion rate in the range $4.4-5.9 \mathrm{~m}^{3} \mathrm{~s}^{-1}$ being recorded on 5 February 2005, with values between 4 and $5 \mathrm{~m}^{3} \mathrm{~s}^{-1}$ being quite common during January 
Fig. 6 ASTER-derived land classification map of Fig. 3 overlain with effusion rate contours for (a) the 2,000-m vent zone and (b) the modified Guest and Murray (1979) vent zone. Vent zone limits are given in yellow and effusion rate contours in black
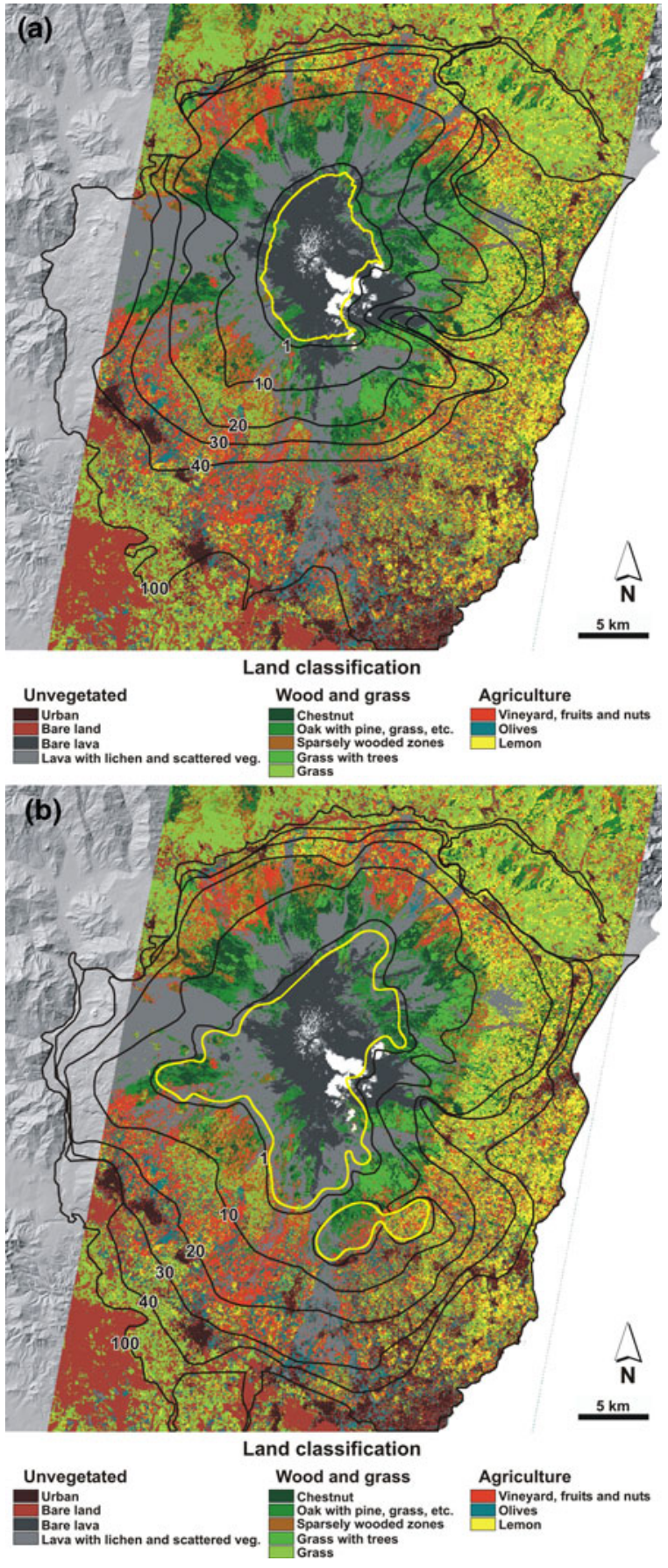

and February 2004 (Harris, unpublished data). Although this is roughly consistent with the flow field lying largely between our 1 and $10 \mathrm{~m}^{3} \mathrm{~s}^{-1}$ contours (Fig. 2a), for the 2004-2005 case, we do appear to underestimate the actual flow field length. This may result from the 

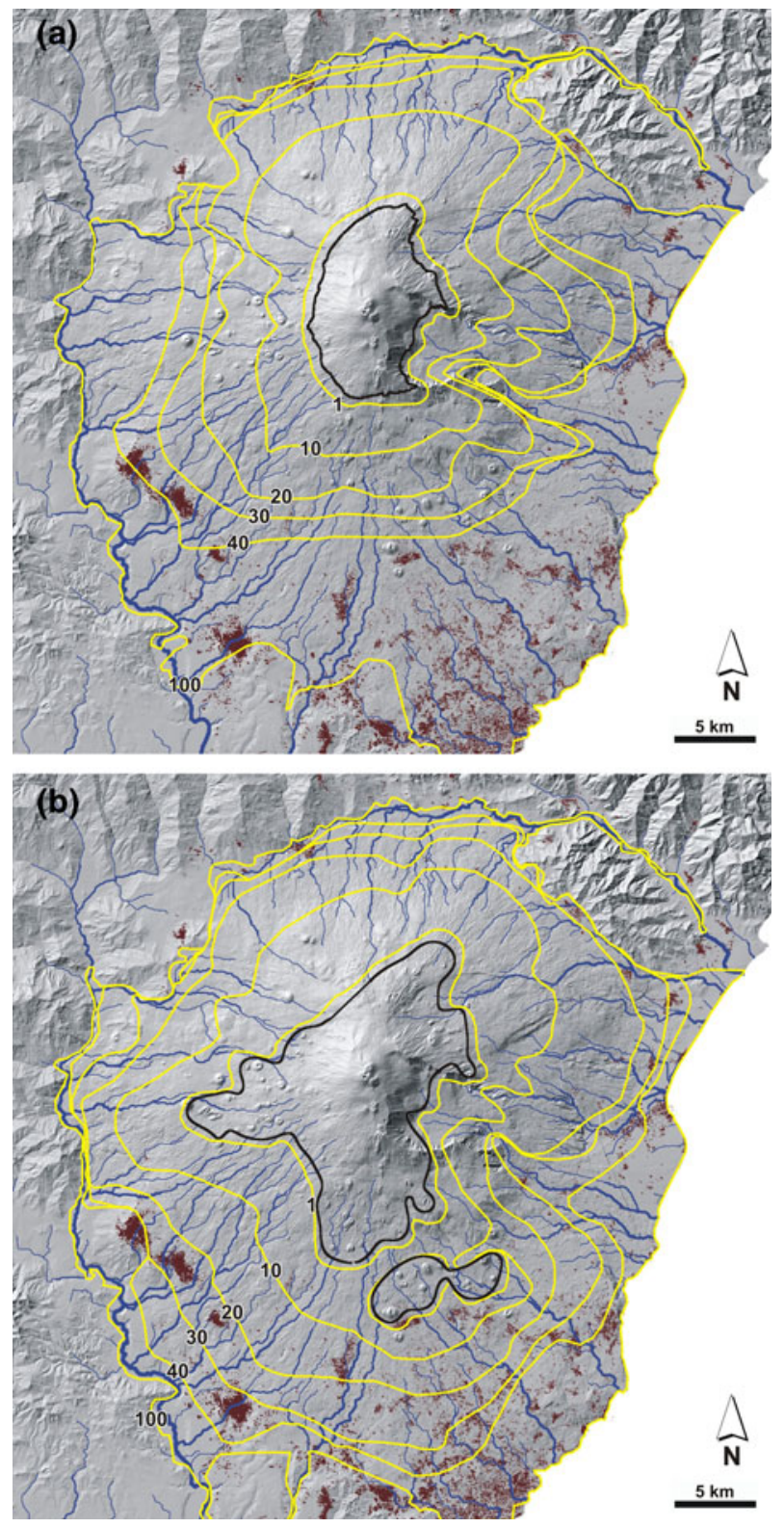

Fig. 7 Main lava drainage lines defined for Mt. Etna with effusion rate contours overlain for (a) the 2,000$\mathrm{m}$ vent zone and (b) the modified Guest and Murray (1979) vent zone. Vent zone limits are given in black, effusion rate contours in yellow and the urban class of our classification in brown

fact that this was a compound flow field, which at times was fed by a complex tube system (Burton et al. 2005). FLOWGO is a model for channel-fed flow, where the development of tubes or well-insulated flow will mean that the lava will have the potential to travel further before reaching is cooling-limited extent at any given effusion rate (Harris and Rowland 
Table 4 Land classification categories, classes, and areas within each effusion rate contour for simulations from the 2,000-m vent region

\begin{tabular}{|c|c|c|c|c|c|c|c|c|}
\hline \multirow[t]{2}{*}{ Category } & \multirow[t]{2}{*}{ Information class } & \multirow{2}{*}{$\begin{array}{l}\text { Above vent } \\
\text { contour } \\
\left(\mathrm{km}^{2}\right)\end{array}$} & \multicolumn{6}{|c|}{$\begin{array}{l}\text { Area occupied by each land cover type } \\
\text { above each } E_{\mathrm{r}}\left(\mathrm{m}^{3} \mathrm{~s}^{-1}\right) \text { contour }\left(\mathrm{km}^{2}\right)\end{array}$} \\
\hline & & & 1 & 10 & 20 & 30 & 40 & 100 \\
\hline \multicolumn{2}{|l|}{ Unclassified } & 5.0 & 6.5 & 7.5 & 7.5 & 7.5 & 7.5 & 7.5 \\
\hline \multirow[t]{4}{*}{ Unvegetated } & Urban & 0.0 & 0.0 & 0.0 & 0.4 & 1.4 & 6.1 & 46.9 \\
\hline & Bare land & 0.0 & 0.0 & 0.1 & 1.9 & 5.2 & 10.6 & 83.1 \\
\hline & Bare lava & 46.5 & 54.3 & 72.8 & 76.2 & 77.2 & 78.0 & 78.9 \\
\hline & Lava w/lichen and scattered veg. & 8.5 & 15.8 & 87.4 & 129.4 & 147.2 & 165.3 & 204.2 \\
\hline \multirow[t]{5}{*}{ Natural veg. } & Chestnut & 0.5 & 2.0 & 29.5 & 49.3 & 62.6 & 67.1 & 77.0 \\
\hline & Oak/pine, grass, etc. & 2.6 & 6.5 & 33.0 & 48.7 & 57.7 & 63.4 & 76.5 \\
\hline & Sparsely wooded & 0.3 & 0.9 & 12.4 & 33.2 & 40.5 & 43.9 & 46.0 \\
\hline & Grass w/trees & 0.1 & 0.6 & 10.8 & 27.9 & 38.6 & 41.4 & 47.8 \\
\hline & Grass & 0.0 & 0.1 & 3.1 & 23.2 & 41.9 & 53.6 & 134.8 \\
\hline \multirow[t]{3}{*}{ Agriculture } & Vineyard, fruit and nuts & 0.0 & 0.1 & 10.6 & 41.6 & 66.5 & 87.5 & 169.0 \\
\hline & Olive & 0.0 & 0.0 & 1.2 & 8.8 & 19.0 & 30.7 & 98.7 \\
\hline & Lemon & 0.0 & 0.0 & 0.1 & 6.1 & 19.8 & 28.9 & 90.2 \\
\hline Unvegetated & All classes & 55.1 & 70.1 & 160.4 & 207.9 & 231.0 & 259.9 & 413.0 \\
\hline Natural veg. & All classes & 3.5 & 10.0 & 88.8 & 182.4 & 241.3 & 269.4 & 382.1 \\
\hline Agriculture & All classes & 0.1 & 0.1 & 11.9 & 56.6 & 105.2 & 147.0 & 357.9 \\
\hline Total & $\begin{array}{l}\text { All classes (including } \\
\text { unclassified) }\end{array}$ & 63.6 & 86.7 & 268.5 & 454.4 & 585.0 & 683.8 & 1160.6 \\
\hline
\end{tabular}

2001; Rowland et al. 2005). Fits between model simulations and field data for single, channel-fed units active within this eruption are, however, excellent if appropriate insulation conditions are used, and if single channel-fed flow units active within the flow field are considered (Harris et al. 2007a). We therefore note that our maps are appropriate for assessing the likely inundation during poorly insulated, channel-fed flow events, and are not appropriate for assessing the impact of well-insulated or tube-fed flow.

\subsection{Effusion rate contours: flow inundation hazard}

On the south flank, eruptions from the 2,000-m vent zone at $40 \mathrm{~m}^{3} \mathrm{~s}^{-1}$ cause lava to extend roughly half the distance between the vent zone and the edge of the volcanic pile, with the $40 \mathrm{~m}^{3} \mathrm{~s}^{-1}$ effusion rate contour roughly coinciding with the 750-m elevation contour (Fig. 2a). This means that anything below this elevation should be safe from inundation by channel-fed flow extending from the $2,000-\mathrm{m}$ elevation at $<40 \mathrm{~m}^{3} \mathrm{~s}^{-1}$. The situation is different on the north flank. Here, flows fed from the 2,000-m elevation vent zone at $40 \mathrm{~m}^{3} \mathrm{~s}^{-1}$ extend more or less to the edge of the volcanic pile. To some extent, this is due to the shorter distance between the 2,000-m vent zone and the edge of the pile on the northern flank when compared to the south. If we consider this in terms of the hazard posed to urban areas (Fig. 7a), we find that most towns lie below the $40 \mathrm{~m}^{3} \mathrm{~s}^{-1}$ effusion rate contour for the 2,000-m vent zone, the exceptions being the west flank towns of Adrano, Biancavilla and Ragaina plus all north flank towns (i.e., the sector 1 municipalities of Table 2). 
Table 5 Land classification categories, classes, and areas within each effusion rate contour for simulations from the Guest and Murray (1979) vent region

\begin{tabular}{|c|c|c|c|c|c|c|c|c|}
\hline \multirow[t]{2}{*}{ Category } & \multirow[t]{2}{*}{ Information class } & \multirow{2}{*}{$\begin{array}{l}\text { Above vent } \\
\text { contour } \\
\left(\mathrm{km}^{2}\right)\end{array}$} & \multicolumn{6}{|c|}{$\begin{array}{l}\text { Area occupied by each land cover type above each } E_{r} \\
\left(\mathrm{~m}^{3} \mathrm{~s}^{-1}\right) \text { contour }\left(\mathrm{km}^{2}\right)\end{array}$} \\
\hline & & & 1 & 10 & 20 & 30 & 40 & 100 \\
\hline Unclassified & & 6.2 & 6.9 & 7.5 & 7.5 & 7.5 & 7.5 & 7.5 \\
\hline \multirow[t]{4}{*}{ Unvegetated } & Urban & 0.1 & 0.4 & 2.2 & 6.1 & 16.1 & 27.6 & 49.6 \\
\hline & Bare land & 0.5 & 1.0 & 5.9 & 16.6 & 32.5 & 49.9 & 93.1 \\
\hline & Bare lava & 60.9 & 66.5 & 75.9 & 78.3 & 78.6 & 78.8 & 78.9 \\
\hline & $\begin{array}{l}\text { Lava w/lichen } \\
\text { and } \\
\text { scattered } \\
\text { veg. }\end{array}$ & 55.8 & 73.2 & 153.1 & 187.7 & 199.3 & 201.6 & 205.6 \\
\hline \multirow[t]{5}{*}{ Natural veg. } & Chestnut & 9.7 & 13.0 & 48.1 & 66.7 & 72.3 & 74.5 & 77.0 \\
\hline & $\begin{array}{l}\text { Oak/pine, } \\
\text { grass, etc. }\end{array}$ & 22.6 & 27.3 & 54.8 & 65.9 & 69.5 & 71.8 & 76.6 \\
\hline & $\begin{array}{l}\text { Sparsely } \\
\text { wooded }\end{array}$ & 3.6 & 4.8 & 23.5 & 42.5 & 45.5 & 46.0 & 46.5 \\
\hline & Grass w/trees & 2.7 & 4.1 & 25.0 & 40.1 & 44.0 & 46.0 & 48.1 \\
\hline & Grass & 2.2 & 3.8 & 20.2 & 56.6 & 81.6 & 102.9 & 144.4 \\
\hline \multirow[t]{3}{*}{ Agriculture } & $\begin{array}{l}\text { Vineyard, } \\
\text { fruit } \\
\text { and nuts }\end{array}$ & 6.2 & 8.6 & 41.9 & 102.0 & 135.7 & 150.8 & 173.7 \\
\hline & Olive & 1.6 & 2.6 & 14.8 & 41.6 & 66.8 & 81.6 & 104.0 \\
\hline & Lemon & 1.2 & 1.4 & 3.3 & 28.3 & 48.5 & 63.4 & 91.4 \\
\hline Unvegetated & All classes & 117.4 & 141.2 & 237.1 & 288.7 & 326.5 & 357.9 & 427.1 \\
\hline Natural veg. & All classes & 40.8 & 53.0 & 171.5 & 271.8 & 312.9 & 341.2 & 392.6 \\
\hline Agriculture & All classes & 8.9 & 12.6 & 60.0 & 171.9 & 251.0 & 295.9 & 369.0 \\
\hline Total & $\begin{array}{l}\text { All classes } \\
\text { (including } \\
\text { unclassified) }\end{array}$ & 173.3 & 213.8 & 476.1 & 739.9 & 897.9 & 1002.6 & 1196.3 \\
\hline
\end{tabular}

The effusion rate contour maps of Fig. 2 show that any flow erupted at $100 \mathrm{~m}^{3} \mathrm{~s}^{-1}$ from the 2,000-m vent zone has the capability to extend to the edge of the volcanic pile, meaning that all communities on the volcano are at risk from such high effusion rate events, as revealed by the run-out of the 1980 flow (Fig. 2a). Of course, some zones are topographically protected from lava flow inundation, as revealed by the grey (flow-path free) zones of Fig. 2. However, inspection of Fig. 7 shows that very few towns do not have drainage paths running through, or near, them.

Because the Guest and Murray (1979) vent zones are located at lower elevations, lava flow contours for runs from this zone are pushed to lower elevations (Fig. 2b). Consequently, the $20 \mathrm{~m}^{3} \mathrm{~s}^{-1}$ effusion rate contour now moves down to around the $750-\mathrm{m}$ elevation on the south flank and the 30 and $40 \mathrm{~m}^{3} \mathrm{~s}^{-1}$ effusion rate contours to around the 250-m elevation. Thus, all zones above this elevation are at risk from lava flows extending from the edge of the Guest and Murray (1979) vent zone at $30-40 \mathrm{~m}^{3} \mathrm{~s}^{-1}$. On the north flank, the 30 and $40 \mathrm{~m}^{3} \mathrm{~s}^{-1}$ contours extend more or less to the edge of the volcanic pile. In terms of hazard to urban areas, inspection of Fig. $7 \mathrm{~b}$ shows that this puts many towns at 


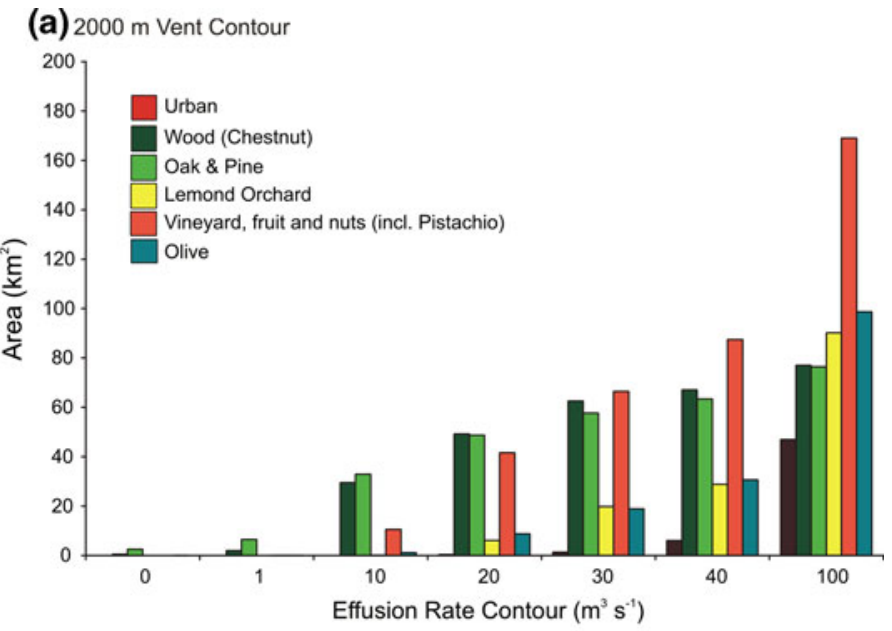

(b) Guest and Murray (1979) Vent Contour

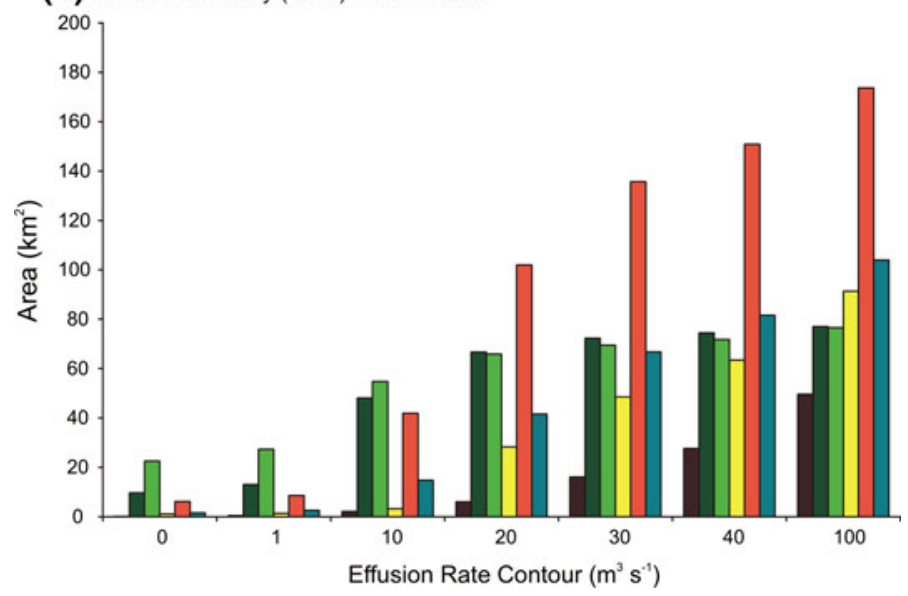

Fig. 8 Amount of each land cover type falling above each effusion rate contour of Fig. 6 for (a) the 2,000m vent zone, and (b) the modified Guest and Murray (1979) vent zone

risk from effusive events fed to $30-40 \mathrm{~m}^{3} \mathrm{~s}^{-1}$ from sources within the Guest and Murray (1979) vent zone. For effusion rates higher than this, all towns are at risk, with the $100 \mathrm{~m}^{3} \mathrm{~s}^{-1}$ effusion rate contour again extending to the edge of the volcanic pile. Note that for the Guest and Murray (1979) vent zone case, the $100 \mathrm{~m}^{3} \mathrm{~s}^{-1}$ flow extends a little further in some places than for the 2,000-m vent zone case to impact slightly more distant communities (c.f., Fig. 2a, b).

\section{Results 2: land classification and land cover distribution around the volcano}

Our land classification results show how we can use remote sensing data to appraise the type and quantity of land at risk from lava flow inundation. The land classification now allows us to precisely quantify the variations in land cover, both by sector and by elevation. 


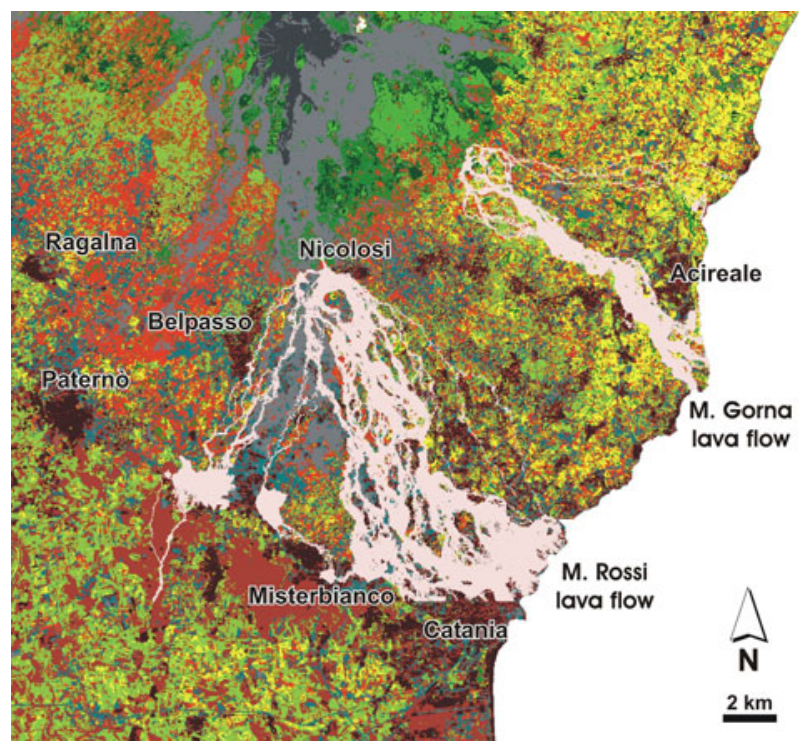

Fig. 9 Results of FLOWGO simulation runs from (1) M. Gorna (eastern flow zone) and (2) M. Rossi (western flow zone). Zone of lava inundation is given in pink and is overlain on the ASTER-derived land classification map of Fig. 3

It thus allows the quantity and type of land at risk from lavas active in a given sector, and/ or extending to given elevations, to be measured.

\subsection{Variation of land cover by sector}

If we examine our land classification by sector, we can quantify the mix of land cover at risk from lava flow inundation within each of the sectors defined in Fig. 1. Given the aspect and altitudinal controls on Etna's land use already described, the balance of this mix varies around the volcano as illustrated in Fig. 4 and quantified in Table 3.

Sector's 2, 3 and 4 are Etna's primary agriculture sectors, accounting for $81 \%$ of Etna's total area assigned to the agricultural land cover category. As is apparent in Fig. 4, the mix of agricultural land cover varies as we move from sector 2 (lemon dominated), through sector 3 (vineyard, fruit, nuts and olives) to sector 4 (vineyard, fruit and nuts). Sector 1 has a reasonable area of agricultural land cover $\left(53.1 \mathrm{~km}^{2}\right.$, Table 3$)$, with vineyards, fruit and nuts being the dominant agricultural land cover, accounting for $14 \%$ of the cover for this sector. Land cover for both sectors 1 and 5 is dominated by unvegetated land, especially lava desert (Fig. 4), with the two sectors accounting for $46 \%$ of the bare lava class defined on Etna (Table 3).

The natural vegetation category is roughly evenly distributed around the volcano (Fig. 4), typically accounting for between 80 and $87 \mathrm{~km}^{2}$ of cover in sectors 1 through 4 . However, the amount is lower $\left(55 \mathrm{~km}^{2}\right)$ in sector 5 (Table 3). Within the natural vegetation category, cover is dominated by the chestnut and oak/pine classes, with both classes being fairly evenly distributed around the volcano (Fig. 4).

6.2 Variation of land cover by elevation

If we examine our land classification by elevation, we can appraise the mix of land cover at risk from lava extending down the volcano's flank and thereby attaining increasingly low 
elevations. As plotted in Fig. 5, the balance of this mix varies with elevation, a result of the altitudinal control on vegetation.

Generally, cultivation is limited to below the 1,000-m contour with $95 \%$ of the agricultural land category occurring at elevations of $\leq 1,000 \mathrm{~m}$. Hence, a lava flow has to extend to below $1,000 \mathrm{~m}$ to impact agriculture. However, there are some differences between each class within our agriculture category. Between sea level and $250 \mathrm{~m}$, lemons are the most dominant of all land cover types. The incidence of lemon groves declines rapidly with elevation so that they are not found above the 500-750 m elevation zone (Fig. 5). Thus, only lava flows extending to low $(<750 \mathrm{~m})$ elevations will impact lemon groves. Olives, in contrast, can grow up to $900 \mathrm{~m}$ (Testi 2003). Hence, the decline in area covered by olives with elevation mirrors that of lemons, but extends to higher elevations (Fig. 5). Cultivation of fruit, nuts and vines extends to the highest altitude zone of the three agricultural types, being found within the 1,250-1,500 m zone (Fig. 5). This is consistent with some varieties of fruit, such as pear and apple being capable of growing at elevations of up to 1,200 $\mathrm{m}$ (Testi 2003). Thus, our fruit, nuts and vines class is the most widespread agricultural class by area and elevation on Etna (Fig. 5).

Figure 5 shows urban cover is also limited to lower elevations, with $49 \%$ of our urban class being located below the $250 \mathrm{~m}$ contour, $78 \%$ below $500 \mathrm{~m}$ and $98 \%$ below $750 \mathrm{~m}$. Less than $0.1 \%$ is located above the $1,000-\mathrm{m}$ contour. Thus, a lava flow has to extend to below $750 \mathrm{~m}$ to impact urban zones.

The area occupied by our natural vegetation classes increases with elevation as agricultural and urban cover decreases (Fig. 5). Above 1,000 m, the natural vegetation category dominates land cover. This is consistent with woodland facing less competition from urban and agricultural land uses at higher elevations. The altitudinal limits for chestnut and oak-pine at Etna (Table 1) mean that both classes are absent above 2,000 m, with the incidence of chestnut dying out first (Fig. 5). Land cover above 2,000 m comprises lava desert (Fig. 5). Thus, lava flows remaining above 2,000 m will solely impact pre-existing lava flow and scoria fields, along with rare pioneer species.

\section{Discussion: lava flow inundation hazard at Mt. Etna}

Whether a given land cover type is at risk will depend on its location in relation to the source vent and lava flow path, as well as effusion rate, as can be assessed using the effusion rate contours. Effusion rate contours overlain on the land classification map are given for the 2,000-m vent zone in Fig. 6a and for the Guest and Murray (1979) vent zone in Fig. 6b. In addition, the area of each land cover type within (above) each effusion rate contour is given in Tables 4 and 5 and is plotted in Fig. 8. Because higher effusion rates cause lava flow to extend further (Walker 1973) and thereby attain lower elevation, the land type area inundated increases with effusion rate (Fig. 8), inverting the trend apparent in the land type area with elevation plot (Fig. 5). Note that a flow fed at $20 \mathrm{~m}^{3} \mathrm{~s}^{-1}$ down a given flow path will cover the same ground inundated by flows extending down the same path at 1 and $10 \mathrm{~m}^{3} \mathrm{~s}^{-1}$, as well as new ground. In turn, a flow fed at $30 \mathrm{~m}^{3} \mathrm{~s}^{-1}$ will cover the same ground as the $20 \mathrm{~m}^{3} \mathrm{~s}^{-1}$ flow, plus new ground. Thus, the plot of lava flow inundation area with effusion rate is cumulative (Fig. 7).

\subsection{Land at risk from eruptions extending from the 2,000-m vent zone}

For the 2,000-m elevation vent zone (Fig. 8a), most land within the vent zone and the $1 \mathrm{~m}^{3} \mathrm{~s}^{-1}$ contour comprises lava desert. Flows fed at $10 \mathrm{~m}^{3} \mathrm{~s}^{-1}$ have the potential to begin to 
impact chestnut and oak/pine woodland, with $\sim 40 \%$ of both classes lying within the $10 \mathrm{~m}^{3}$ $\mathrm{s}^{-1}$ contour and $64 \%$ within the $20 \mathrm{~m}^{3} \mathrm{~s}^{-1}$ contour (Table 4). Of the agricultural category, the vineyard-fruit-nut class (being the agricultural class capable of growing at highest elevations) is the first to suffer potential impact (Fig. 8a), with $6 \%$ of this class lying within the $10 \mathrm{~m}^{3} \mathrm{~s}^{-1}$ contour and $25 \%$ within the $20 \mathrm{~m}^{3} \mathrm{~s}^{-1}$ contour (Table 4). Both the lemon class and the olive class begin to register within the $20 \mathrm{~m}^{3} \mathrm{~s}^{-1}$ contour (Fig. 8a), with the area of all agricultural categories contained within a particular contour increasing steadily with effusion rate for all contours thereafter, with $100 \%$ of all agricultural categories falling within the $100 \mathrm{~m}^{3} \mathrm{~s}^{-1}$ contour (Table 4). The urban class does not register until the $30 \mathrm{~m}^{3} \mathrm{~s}^{-1}$ contour (Fig. 8a), although this contour contains just $3 \%$ of the urban area. The $40 \mathrm{~m}^{3} \mathrm{~s}^{-1}$ contour still only contains $13 \%$ of the urban area, but the $100 \mathrm{~m}^{3} \mathrm{~s}^{-1}$ contains $100 \%$ of the urban area located on Etna (Table 4). In short, for the 2,000-m vent zone:

- Lava flows fed at $<10 \mathrm{~m}^{3} \mathrm{~s}^{-1}$ will only spread over lava desert.

- Lava flows fed at $10-20 \mathrm{~m}^{3} \mathrm{~s}^{-1}$ have the potential to extend into woodland.

- Lava flows fed at $>20 \mathrm{~m}^{3} \mathrm{~s}^{-1}$ have the potential to extend into agriculture and those at $>30 \mathrm{~m}^{3} \mathrm{~s}^{-1}$ have the potential to extend into agricultural and urban zones, with the potential for impact (in terms of vulnerable area within each contour, Table 4) increasing with effusion rate.

\subsection{Land at risk from eruptions extending from the Guest and Murray (1979) vent zone}

Because the Guest and Murray (1979) vent zone is located closer to, or in some cases within, wooded and cultivated zones, some non-barren-lava types actually occur within the vent zone itself, as well as within the $1 \mathrm{~m}^{3} \mathrm{~s}^{-1}$ contour (Fig. 8b). As a result, the $10 \mathrm{~m}^{3} \mathrm{~s}^{-1}$ contour also contains much more vulnerable woodland and agricultural land than the same contour on the 2,000-m vent zone map (c.f. Tables 4 and 5). Flows fed at $10 \mathrm{~m}^{3} \mathrm{~s}^{-1}$ have the potential to impact $62 \%$ of the chestnut class, and $71 \%$ of the oak/pine class, with $86 \%$ of both classes falling within the $20 \mathrm{~m}^{3} \mathrm{~s}^{-1}$ contour. The area of all agricultural categories falling within a given effusion rate contour increases steadily for all contours, increasing after the $1 \mathrm{~m}^{3} \mathrm{~s}^{-1}$ contour for the vineyard-fruit-nut class, and after the $10 \mathrm{~m}^{3} \mathrm{~s}^{-1}$ contour for both the lemons and olives class. The $30 \mathrm{~m}^{3} \mathrm{~s}^{-1}$ contour contains $78 \%$ of the vineyard-fruit-nut class, $64 \%$ of the olives class and $53 \%$ of the lemons class. The urban class begins to register within the $10 \mathrm{~m}^{3} \mathrm{~s}^{-1}$ contour, although this contour contains just $4 \%$ of the total urban area. The 20,30 and $40 \mathrm{~m}^{3} \mathrm{~s}^{-1}$ contours each contain 12,32 and $56 \%$ of the urban area, with the $100 \mathrm{~m}^{3} \mathrm{~s}^{-1}$ contour containing $100 \%$ of the urban area. The $100 \mathrm{~m}^{3} \mathrm{~s}^{-1}$ actually contains $100 \%$ of Etna's area, and hence, all land cover types. In short, for the Guest and Murray (1979) vent zone:

- Lava flows fed at $1-10 \mathrm{~m}^{3} \mathrm{~s}^{-1}$ have the potential to extend into woodland and agricultural zones.

- Lava flows fed at $20 \mathrm{~m}^{3} \mathrm{~s}^{-1}$ have the potential to extend into most of Etna's woodland.

- Lava flows fed at $>20 \mathrm{~m}^{3} \mathrm{~s}^{-1}$ have the potential to extend into agriculture and urban zones, with the potential for impact (in terms of vulnerable area within each contour, Table 4) increasing with effusion rate.

\subsection{Land at risk from specific eruptions}

The approach can also be run in a more case-specific style to either (1) assess the potential inundation of a hypothetical flow from a single vent location and effusion rate, or (2) 
Table 6 Land classes impacted by modelled lava flow fields from (1) M. Gorna and (2) M. Rosi (Fig. 9)

\begin{tabular}{|c|c|c|c|c|c|}
\hline \multirow[t]{2}{*}{ Category } & \multirow[t]{2}{*}{ Information class } & \multicolumn{2}{|l|}{ Area $\left(\mathrm{m}^{2}\right)$} & \multicolumn{2}{|l|}{ Per cent } \\
\hline & & M. Gorna & M. Rosi & M. Gorna & M. Rosi \\
\hline \multirow[t]{4}{*}{ Unvegetated } & Urban & $5.90 \mathrm{E}+05$ & $1.07 \mathrm{E}+07$ & 5 & 23 \\
\hline & Bare land & $9.61 \mathrm{E}+05$ & $1.18 \mathrm{E}+07$ & 8 & 26 \\
\hline & Bare lava & $3.38 \mathrm{E}+03$ & $0.00 \mathrm{E}+00$ & 0 & 0 \\
\hline & Lava w/lichen and scattered veg & $1.95 \mathrm{E}+05$ & $3.72 \mathrm{E}+06$ & 2 & 8 \\
\hline \multirow[t]{5}{*}{ Natural veg. } & Chestnut & $1.82 \mathrm{E}+05$ & $3.15 \mathrm{E}+03$ & 2 & 0 \\
\hline & Oak/pine, grass, etc. & $4.28 \mathrm{E}+05$ & $1.85 \mathrm{E}+05$ & 4 & 0 \\
\hline & Sparsely wooded & $2.00 \mathrm{E}+04$ & $6.08 \mathrm{E}+03$ & 0 & 0 \\
\hline & Grass w/trees & $1.48 \mathrm{E}+05$ & $3.15 \mathrm{E}+04$ & 1 & 0 \\
\hline & Grass & $2.18 \mathrm{E}+06$ & $3.62 \mathrm{E}+06$ & 18 & 8 \\
\hline \multirow[t]{3}{*}{ Agriculture } & Vineyard, fruit and nuts & $2.83 \mathrm{E}+06$ & $5.22 \mathrm{E}+06$ & 24 & 11 \\
\hline & Olive & $1.46 \mathrm{E}+06$ & $9.58 \mathrm{E}+06$ & 12 & 21 \\
\hline & Lemon & $2.98 \mathrm{E}+06$ & $8.04 \mathrm{E}+05$ & 25 & 2 \\
\hline Total & All classes & $1.20 \mathrm{E}+07$ & $4.57 \mathrm{E}+07$ & 100 & 100 \\
\hline
\end{tabular}

project the likely inundation zone during an ongoing eruption. In the latter case, projecting the simulations over the land cover map would allow a rapid assessment of the type and area of land at risk as soon as the vent location and effusion rate are known. By way of example, we ran two simulations from within the Guest and Murray (1979) vent zone. The first simulation was from the Monte Gorna cinder cone at an elevation of $850 \mathrm{~m}$ on Etna's NE flank, the second was from the Monte Rossi cone at an elevation of $940 \mathrm{~m}$ on the same flank (Fig. 9). While Monte Gorna is attributed to Etna's 396 BC eruption, Monte Rossi was active in 1669 (Del Carlo and Branca 1998). The simulations were run to the coast using $\Delta \mathrm{h}$ of $3 \mathrm{~m}$ and 10,000 iterations; both took less than a minute to run. Results are given in Fig. 9. In both cases, the low elevation of the vents places the lava source within populated and cultivated zones, the Monte Rossi vent is actually in the town of Nicolosi and was the vent for the 1669 flow that inundated Catania. Figure 9 shows that while the Monte Rossi flows present an inundation hazard for the Communes of Nicolosi, Belpasso, Misterbianco and Catania (see also Crisci et al. 2004), those of Monte Gorna extend through Acireale. The inundation statistics for the two simulated flows are given in Table 6. These show that the Monte Gorna simulation inundates $12 \mathrm{~km}^{2}$ of land, with impact weighted towards agricultural land uses (Fig. 10). The Monte Rossi simulation, on the other hand, inundates $46 \mathrm{~km}^{2}$ of land, with impact weighted towards urban land uses, although olives face significant inundation problems (Fig. 10).

\section{Conclusion}

Our effusion rate contour maps are designed to provide a quick look-up capability to assess where and how far a lava flow, extending from a given vent zone location and at a known effusion rate, will spread. We give no assessment as to the likelihood of a certain point within each effusion rate contour being attained. This is the role of probabilistic maps, such as that provided for lava flow inundation at Mt. Etna by Favalli et al. (2009a) or Crisci et al. 


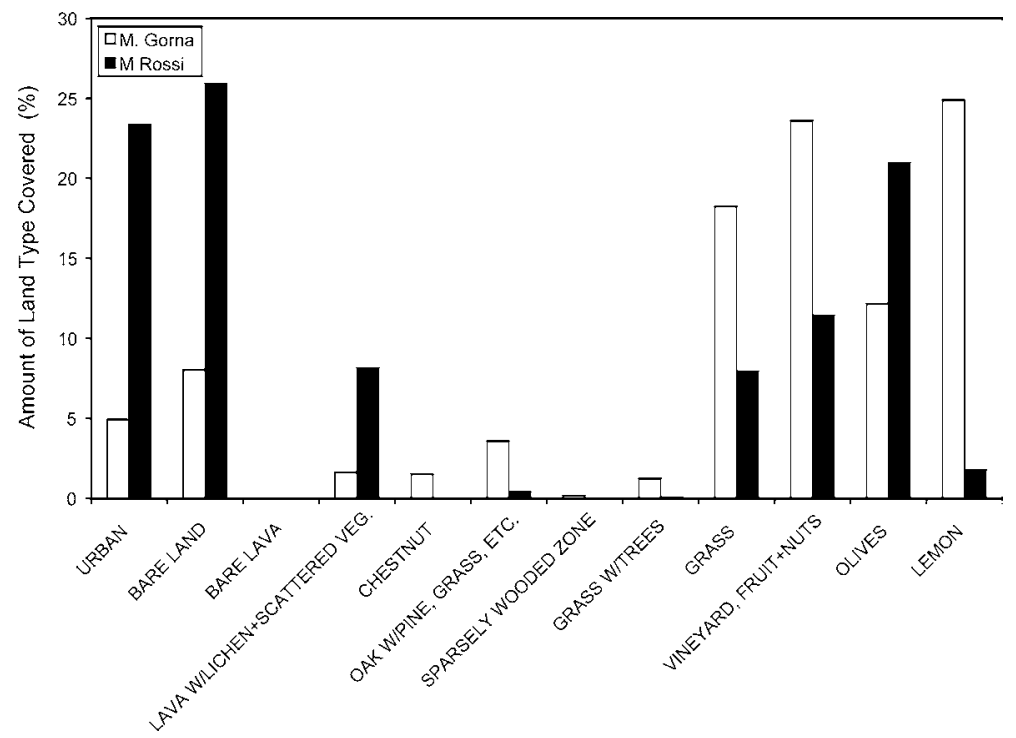

Fig. 10 Per cent of each land cover type inundated by FLOWGO simulated flows from the (1) M. Gorna and (2) M. Rossi vents

(2010). Instead, what we aim at is a complete map that encompasses any effusive eruption eventuality, i.e., a quick look-up map that will reveal the inundation potential for any point on the volcano from any vent location and erupting at any effusion rate, no matter what the probability of that vent location, flow path and effusion rate combination. As a result, our map should be flexible and generally applicable to any effusive eruption from any likely vent opening point.

The use of the effusion rate contours with a satellite-derived land classification map allows an assessment of both the type and area of land cover at risk from lava inundation. The advantage of using satellite data as the basis for the land cover map is that it can be frequently, and easily, up dated (with each cloud-free satellite overpass if necessary) to take into account developing distributions of land cover. In addition, it is flexible, where such maps can be created for any point on the Earth's surface. As such, the approach can be extended beyond Etna, especially to locations where adequate land use maps are lacking. It can also be extended to other volcanic hazard types (e.g., inundation by mud or debris flow) or scenario's, such as the potential of sea level rise to endanger habitat on low elevation islands (e.g., Baker et al. 2006).

It is well known that mapping of past volcanic flows (including pyroclastic and lava flows) can be incorporated into geographical information systems, containing land use and infrastructure layers, to allow assessment of the hazard posed to infrastructure and urban areas by flow ingress (e.g., Kauahikaua et al. 1995; Trusdell 1995; Lirer and Vitelli 1998; Gomez-Fernandez 2000; Pareschi et al. 2000; Behncke et al. 2005; Bisson et al. 2009). We show here that simulations completed using reliable flow emplacement models, when integrated with satellite-based land classification maps, allow input of critical layers of information for use by the hazard manager to assess the type and area of land at risk from lava flow inundation. This may be used to guide hazard response efforts in terms of 
planning an appropriate response, formulating mitigation, modification, and relief efforts, as well as assessing potential loss and replacement costs.

Acknowledgments This work was funded by NASA Grant NNG04GO64G "new tools for advanced hot spot tracking using MODIS thermal alerts". We are extremely grateful to the INGV-Catania, Sonia Calvari, and Luigi Lodato for providing field support during the two seasons of field checking, as well as to an anonymous reviewer and Gianluca Norini for providing two positive and constructive reviews.

\section{References}

Alexis H, Vicari A, Ciraudo A, Del Negro C (2009) Forecasting lava flow hazards during the 2006 Etna eruption: using the MAGFLOW cellular automata model. Comput Geosci 35:1050-1060

Andronico D, Branca S, Calvari S, Burton M, Caltabiano T, Corsaro RA, Del Carlo P, Garfi G, Lodato L, Miragila L, Murè F, Neri M, Pecora E, Pompilio M, Salerno G, Spampinato L (2005) A multidisciplinary study of the 2002-2003 Etna eruption: insights into a complex plumbing system. Bull Volcanol 67:314-330

Baker JD, Littnan CL, Johnston DW (2006) Potential effects of sea level rise on the terrestrial habitats of endangered species and endemic megafauna in the Northwestern Hawaiian Islands. Endang Species Res 4:1-10

Barberi F, Carapezza ML, Valenza M, Villari L (1993) The control of lava flow during the 1991-1992 eruption of Mt. Etna. J Volcanol Geotherm Res 56:1-34

Barca D, Crisci GM, Di Gregorio S, Nicoletta F (1993) Cellular automata methods for modeling lava flows: simulation of the 1986-1987 eruption, Mount Etna, Sicily. In: Kilburn CRJ, Luongo G (eds) Active lavas. UCL Press, London, pp 291-309

Behncke B, Neri M (2003) The July-August 2001 eruption of Mt. Etna (Sicily). Bull Volcanol 65:461-476

Behncke B, Neri M, Nagay A (2005) Lava flow hazard at Mount Etna (Italy): new data from a GIS-based study. Geol Soc Am Special Paper 396:189-207

Bisson M, Behncke B, Fornaciai A, Neri M (2009) LiDAR-based digital terrain analysis of an area exposed to the risk of lava flow invasion: the Zafferana Etnea territory, Mt. Etna (Italy). Nat Hazards 50:321-334

Blong RJ (1984) Volcanic hazards. Academic Press, Sydney, 424 p

Bonne K, Kervyn M, Cascone L, Njome S, Van Ranst E, Suh E, Ayonghe S, Jacobs P, Ernst G (2008) A new approach to assess long-term lava flow hazard and risk using GIS and low-cost remote sensing: the case of Mount Cameroon, West Africa. Int J Remote Sensing 29(22):6539-6564

Burton MR, Neri M, Andronico D, Branca S, Caltabiano T, Calvari S, Corsaro RA, Del Carlo P, Lanzafame G, Lodato L, Miraglia L, Salerno G, Spampinato L (2005) Etna 2004-2005: an archetype for geodynamically-controlled effusive eruptions. Geophys Res Lett 32:L09303. doi:10.1029/2005GL022527

Calvari S, Coltelli M, Neri M, Pompilio M, Scribano V (1994) The 1991-1993 Etna eruption: chronology and geological observations. Acta Vulcanol 4:1-15

Calvari S, Neri M, Pinkerton H (2003) Effusion rate estimations during the 1999 summit eruption on Mount Etna, and growth of two distinct lava flow fields. J Volcanol Geotherm Res 119:107-123

Chester DK, Duncan AM, Guest JE, Kilburn CRJ (1985) Mount Etna: the anatomy of a volcano. Chapman and Hall, London, 187-228 p

Chester DK, Duncan AM, Dibben C, Guest JE, Lister PH (1999) Mascali, Mount Etna Region Sicily: an example of fascist planning during the 1928 eruption and its continuing legacy. Nat Hazards 19:29-46

Chirico GD, Favalli M, Papale P, Boschi E, Pareschi MT, Mamou-Mani A (2009) Lava flow hazard at Nyiragongo Volcano, DRC 2. Hazard reduction in urban areas. Bull Volcanol 71:375-387

Coltelli M, Proietti C, Branca S, Marsella M, Andronico D, Lodato L (2007) Analysis of the 2001 lava flow eruption of Mt. Etna from three-dimensional mapping. J Geophys Res 112: F02029. doi: 10.1029/2006JF000598

Crisci GM, Di Gregorio S, Pindaro O, Ramieri G (1986) Lava flow simulation by a discrete cellular model: first implementation. Int J Model Simul 6:137-140

Crisci GM, Di Gregorio S, Nicoletta F, Rongo R, Spataro W (1999) Analysing lava risk for the Etnean area: simulation by cellular automata methods. Nat Hazards 20:215-229

Crisci GM, Di Gregorio S, Rongo R, Scarpelli M, Spataro W, Calvari S (2003) Revisiting the 1669 Etnean eruptive crisis using a cellular automata model and implications for volcanic hazard in the Catania area. J Volcanol Geotherm Res 123:211-230 
Crisci G, Rongo R, Gregorio S, Spataro W (2004) The simulation model SCIARA: the 1991 and 2001 lava flows at Mount Etna. J Volcanol Geotherm Res 132:253-267

Crisci GM, Iovine G, Di Gregorio S, Lupaino V (2008) Lava-flow hazard on the SE flank of Mt. Etna (Southern Italy). J Volcanol Geotherm Res 177:778-796

Crisci GM, Avolio MV, Behncke B, D’Ambrosio D, Di Gregorio S, Lupiano V, Neri M, Rongo R, Spataro W (2010) Predicting the impact of lava flows at Mount Etna, Italy. J Geophys Res 115:B04203. doi: 10.1029/2009JB006431

Damiani ML, Gropelli G, Norini G, Bertino E, Gigliuto A, Nucita A (2006) A lava flow simulation model for the development of volcanic hazard maps for Mount Etna (Italy). Comput Geosci 32:512-526

Del Carlo C, Branca S (1998) Tephrostratigraphic dating of the pre-1300 AD SE flank eruptions of Mt Etna. Acta Vulcanol 10(1):33-37

Del Negro C, Fortuna L, Vicari A (2005) Modelling lava flows by cellular nonlinear networks $(\mathrm{CNN})$ : preliminary results. Nonlinear Process Geophys 12:505-513

Del Negro C, Fortuna L, Herault A, Vicari A (2008) Simulations of the 2004 lava flow at Etna volcano by the MAGFLOW cellular automata model. Bull Volcanol 70(7):805-812

Duncan AM, Dibben CD, Chester DK, Guest JE (1996) The 1928 eruption of Mount Etna Volcano, Sicily, and the destruction of the town of Mescali. Disasters 20(1):1-45

Favalli M, Pareschi M, Neri A, Isola I (2005) Forecasting lava flow paths by a stochastic approach. Geophys Res Lett 32:L03305. doi:10.1029/2004GL021718

Favalli M, Chirico GD, Papale P, Pareschi MT, Coltelli M, Lucaya N, Boschi E (2006) Computer simulations of lava flow paths in the town of Goma, Nyiragongo volcano, Democratic Republic of Congo. J Geophys Res 111:B06202. doi:10.1029/2004JB003527

Favalli M, Mazzarini F, Pareschi MT, Boschi E (2009a) Topographic control on lava flow paths at Mount Etna, Italy: Implications for hazard assessment. J Geophys Res 114:F01019. doi:10.1029/2007JB00 0918

Favalli M, Chirico GD, Papale P, Pareschi MT, Boschi E (2009b) Lava flow hazard at Nyiragongo Volcano, DRC 1. Model calibration and hazard mapping. Bull Volcanol 71:63-374

Felpeto A, Arana V, Ortiz R, Astiz M, Garcia A (2001) Assessment and modelling of lava flow hazard on Lanzarote (Canary Islands). Nat Hazards 23:247-257

Forgione G, Luongo G, Romano R (1989) Mt Etna (Sicily): volcanic hazard assessment. In: Latter JH (ed) IAVCEI Proceedings in volcanology 1. Springer-Verlag, Berlin, pp 137-150

Frazzetta G, Romano R (1984) The 1983 Etna eruption: Event chronology and morphological evolution of the lava flow. Bull Volcanol 47:1079-1096

Fujita E, Hidaka M, Goto A, Umino S (2009) Simulations of measures to control lava flows. Bull Volcanol 71:401-408

Glaze LS, Baloga SM (2001) User's manual for lava flow path prediction algorithm. Proxemy Research, Laytonsville, $32 \mathrm{p}$

Gomez-Fernandez F (2000) Application of a GIS algorithm to delimit the areas protected against basic lava flow invasion on Tenerife Island. J Volcanol Geotherm Res 103:409-423

Guest JE, Murray JB (1979) An analysis of hazard from Mount Etna volcano. J Geol Soc Lond 136:347-354

Guest JE, Kilburn CRL, Pinkerton H, Duncan AM (1987) The evolution of lava flow-fields: observations of the 1981 and 1983 eruptions of Mount Etna, Sicily. Bull Volcanol 49:527-540

Harris AJL, Neri M (2002) Volumetric observations during paroxysmal eruptions at Mount Etna: pressurized drainage of a shallow chamber or pulsed supply? J Volcanol Geotherm Res 116:79-95

Harris A, Rowland S (2001) FLOWGO: a kinematic thermo-rheological model for lava flowing in a channel. Bull Volcanol 63:20-44

Harris AJL, Blake S, Rothery DA, Stevens NF (1997) A chronology of the 1991 to 1993 Mount Etna eruption using advanced very high resolution radiometer data: implications for real-time thermal volcano monitoring. Geophys Res Lett 102:7985-8003

Harris AJL, Murray JB, Aries SE, Davies MA, Flynn LP, Wooster MJ, Wright R, Rothery DA (2000) Effusion rate trends at Etna and Krafla and their implications for eruptive mechanisms. J Volcanol Geotherm Res 102:237-270

Harris A, Favalli M, Mazzarini F, Pareschi MT (2007a) Best-fit results from application of a thermorheological model for channelized lava flow to high spatial resolution morphological data. Geophys Res Lett 34:L01301. doi:10.1029/2006GL028126

Harris AJL, Dehn J, Calvari S (2007b) Lava effusion rate definition and measurement: a review. Bull Volcanol 70:1-22

Hidaka M, Goto A, Susumu U, Fujita E (2005) VTFS project: Development of the lava flow simulation code LavaSIM with a model for three-dimensional convection, spreading, and solidification. Geochem Geophys Geosystems 6(7):Q07008. doi:10.1029/2004GC000869 
ISTAT (2008) Demografia in cifre. Istituto Nazionale di Statistica, Roma, Italy. http://demo.istat.it/

Kauahikaua J, Margriter S, Lockwood J, Trusdell F (1995) Applications of GIS to the estimation of lava flow hazards on Mauna Loa Volcano, Hawai'i. AGU Geophys Monogr 92:315-325

Lautze NC, Harris AJL, Bailey J, Ripepe M, Calvari S, Dehn J, Rowland S, Evans-Jones K (2004) Evidence for pulsed magma supply at Mount Etna during 2001. J Volcanol Geotherm Res 137:231-246

Lillesand TM, Kiefer RW (1987) Remote sensing and image interpretation, 2nd edn. Wiley, New York. $721 \mathrm{p}$

Lirer L, Vitelli L (1998) Volcanic risk assessment and mapping in the Vesuvian area using GIS. Nat Hazards $17: 1-15$

Mather PM (1987) Computer processing of remotely-sensed images. Wiley, Chichester, $352 \mathrm{p}$

Pareschi MT, Cavarra L, Favalli M, Giannini F, Meriggi A (2000) GIS and volcanic risk management. Nat Hazards 21:361-379

Poli Marchese E (1991) Piante e fiori dell'Etna. Sellerio, Palermo, 198 p

Proietti C, Coltelli M, Marsella M, Fujita E (2009) A quantitative approach for evaluating lava flow simulation reliability: LavaSIM code applied to the 2001 Etna eruption. Geochem Geophys Geosystems 10(9):09003. doi:10.1029/2009GC002426

Puzzolo V, Folving S (2001) A GIS integration of topographic, geological and climatic data for the analysis of the Mt Etna forests distribution (Sicily, Italy). Proceedings of the 7th EC-GI and GIS workshop EGII, Potsdam, Germany, pp 1-11

Rowland S, Garbeil H, Harris A (2005) Lengths and hazards from channel-fed lava flows on Mauna Loa, Hawai'i, determined from thermal and downslope modeling with FLOWGO. Bull Volcanol 67:634-647

Testi A (2003) Alberi d'Italia. Giunti Editore, Firenze-Milano, 383 p

Trusdell FA (1995) Lava flow hazards and risk assessment on Mauna Loa, Hawaii. AGU Geophys Monogr 92:327-336

Vicari A, Alexis H, Del Negro C, Coltelli M, Marsella M, Proietti C (2007) Modeling of the 2001 lava flow at Etna volcano by a cellular automata approach. Environ Model Softw 22:1464-1471

Vicari A, Ciraudo A, Del Negro C, Herault A, Fortuna L (2009) Lava flow simulations using discharge rates from thermal infrared satellite imagery during the 2006 Etna eruption. Nat Hazards 50:539-550

Villari L (1983) Volcano surveillance and volcanic hazard assessment in the Etnean area. In: Tazieff H, Sabroux J-C (eds) Forecasting volcanic events. Elsevier, Amsterdam, pp 131-147

Wadge G, Young PAV, McKendrick IJ (1994) Mapping lava flow hazards using computer simulation. J Geophys Res 99(B1):489-504

Walker GPL (1973) Lengths of Lava Flows. Philos Trans Roy Soc Lond 274:107-118

Wright R, Garbeil H, Harris AJL (2008) Using infrared satellite data to drive a thermo-rheological/stochastic lava flow emplacement model: a method for near-real-time volcanic hazard assessment. Geophys Res Lett 35:L19307. doi:10.1029/2008GL035228

Young P, Wadge G (1990) FLOWFRONT: simulation of a lava flow. Comput Geosci 16:1171-1191 